\title{
Grafted block complex coacervate core micelles and their effect on protein adsorption on silica and polystyrene
}

\author{
Agata M. Brzozowska • Arie de Keizer • Willem Norde • \\ Christophe Detrembleur • Martien A. Cohen Stuart
}

Received: 24 November 2009/Revised: 15 April 2010 /Accepted: 18 April 2010 /Published online: 13 May 2010

(C) The Author(s) 2010. This article is published with open access at Springerlink.com

\begin{abstract}
We have studied the formation and the stability of grafted block complex coacervate core micelles (C3Ms) in solution and the influence of grafted block C3M coatings on the adsorption of the proteins $\beta$-lactoglobulin, bovine serum albumin, and lysozyme. The C3Ms consist of a grafted block copolymer $\mathrm{PAA}_{21}-b-\mathrm{PAPEO}_{14}$ (poly(acrylic acid)- $b$-poly(acrylate methoxy poly(ethylene oxide)), with a negatively charged PAA block and a neutral PAPEO block and a positively charged homopolymer P2MVPI (poly $(N$ methyl 2-vinyl pyridinium iodide). In solution, these C3Ms partly disintegrate at salt concentrations between 50 and $100 \mathrm{mM} \mathrm{NaCl}$. Adsorption of C3Ms and proteins has been studied with fixed-angle optical reflectometry, at salt concentrations ranging from 1 to $100 \mathrm{mM} \mathrm{NaCl}$. In comparison with the adsorption of $\mathrm{PAA}_{21}-b-\mathrm{PAPEO}_{14}$
\end{abstract}

A. M. Brzozowska $(\bowtie) \cdot$ A. de Keizer $\cdot$ W. Norde $\cdot$

M. A. Cohen Stuart

Laboratory of Physical Chemistry and Colloid Science,

Wageningen University,

Dreijenplein 6,

6703 HB Wageningen, The Netherlands

e-mail: agata.brzozowska@wur.nl

\section{A. M. Brzozowska}

Wetsus, Centre of Excellence for Sustainable Water Technology,

Agora 1, P.O. Box 1113, 8900 CC Leeuwarden, The Netherlands

\section{W. Norde}

Department of Biomedical Engineering,

University Medical Center Groningen and University of Groningen,

A. Deusinglaan 1,

9713 AV Groningen, The Netherlands

\section{Detrembleur}

Centre d'Etude et de Recherche sur les Macromolécules,

Université de Liège,

Sart-Tilman B6a,

4000 Liège, Belgium alone adsorption of $\mathrm{C} 3 \mathrm{Ms}$ significantly increases the amount of $\mathrm{PAA}_{21}-b-\mathrm{PAPEO}_{14}$ on the surface. This results in a higher surface density of PEO chains. The stability of the $\mathrm{C} 3 \mathrm{M}$ coatings and their influence on protein adsorption are determined by the composition and the stability of the C3Ms in solution. A C3M-PAPEO ${ }_{14} / \mathrm{P}_{2} \mathrm{MVPI}_{43}$ coating strongly suppresses the adsorption of all proteins on silica and polystyrene. The reduction of protein adsorption is the highest at $100 \mathrm{mM} \mathrm{NaCl}(>90 \%)$. The adsorbed C3M$\mathrm{PAPEO}_{14} / \mathrm{P}_{2} \mathrm{MVPI}_{43}$ layer is partly removed from the surface upon exposure to an excess of $\beta$-lactoglobulin solution, due to formation of soluble aggregates consisting of $\beta$-lactoglobulin and $\mathrm{P}_{2} \mathrm{MVPI}_{43}$. In contrast, $\mathrm{C} 3 \mathrm{M}$ $\mathrm{PAPEO}_{14} / \mathrm{P}_{2} \mathrm{MVPI}_{228}$ which has a fivefold longer cationic block enhances adsorption of the negatively charged proteins on both surfaces at salt concentrations above $1 \mathrm{mM} \mathrm{NaCl}$. A single $\mathrm{PAA}_{21}-b$ - $\mathrm{PAPEO}_{14}$ layer causes only a moderate reduction of protein adsorption.

Keywords Grafted block copolymer - Complex coacervate core micelles · Protein adsorption · Silica · Polystyrene

\section{Introduction}

In polymer brush coatings, the grafting density is an important parameter in suppressing protein adsorption. Densely grafted polymer chains prevent penetration of the brush by protein molecules and, as a consequence, suppress adsorption of proteins on the native surface (primary adsorption) [1]. Relatively high brush densities can be obtained by chemical grafting of polymer chains to the surfaces ("grafting to" and "grafting from" methods). However, these methods are time-consuming and require several preparation steps. In recent papers [2-4], we 
reported on the formation of brush layers by adsorbing reversible, self-assembled micellar structures known as "complex coacervate core micelles" (C3Ms) [5], also called "block ionomer complexes" [6] or "polyion complex micelles" [7]. C3Ms are formed upon mixing oppositely charged polyelectrolytes, of which at least one contains a neutral soluble block. Due to electrostatic attraction, the oppositely charged blocks form the coacervate core which is stabilized by the neutral corona blocks $[5,8,9]$. Upon addition of homopolymers to oppositely charged diblock copolymers in sub-stoichiometric amounts, charged, loose structures with low aggregation numbers, so-called soluble complex particles (SCPs), are formed. At a critical composition, close to stoichiometry, neutral $\mathrm{C} 3 \mathrm{Ms}$ are formed, and the number of SCPs decreases to zero at the preferred micellar composition (PMC). The charge composition (mixing ratio) of $\mathrm{C} 3 \mathrm{Ms}$ may be defined by the ratio $(f-)$ of the number of negatively chargeable groups to the total number of (negatively and positively) chargeable groups. A mechanism of the interaction of C3Ms with solid-liquid interfaces has been proposed previously by van der Burgh et al. [4] and Voets et al. [10]. According to this model, upon adsorption at the interface, C3Ms unfold in such a way that their corona forms a brush on top of a coacervate layer attached directly to the solid-liquid interface (Fig. 1a). The effect of a C3M coating on protein adsorption strongly depends on its composition and structure, the surface properties, and the salt concentration [2]. The densities of the brushes thus formed by the C3M systems were found to be rather low and often insufficient to fully suppress adsorption of proteins [2]. In the present paper, we focus on the improvement of the density of the $\mathrm{C} 3 \mathrm{M}$ brush. The brush density may be increased by adsorption of comb copolymers [11-13] or grafted block copolymers instead of linear polymers (Fig. 1b). The density of the neutral brush-forming chains is partly predetermined by the density of their chemical grafting to the backbone. However, adsorption of such chains on a solidliquid interface may result in low surface coverage and, hence, in low overall brush density. Here, we combine the high density of the neutral chains in grafted block copolymers with the formation of C3Ms (Fig. 1c). This approach may allow for an increase of the brush density resulting in a better reduction of protein adsorption.

The aim of this work is to investigate the formation and stability of grafted block C3Ms in solution, their adsorption on silica and polystyrene, and the effect of the adsorbed $\mathrm{C} 3 \mathrm{M}$ layer on protein adsorption.

\section{Materials and methods}

Chemicals

Poly(2-vinyl pyridine)- $b$-poly(ethylene oxide) $\left(\mathrm{P}^{2} \mathrm{VP}_{41}-b\right.$ $\mathrm{PEO}_{204}, M_{\mathrm{n}}=13.3 \mathrm{~kg} / \mathrm{mol}$, polydispersity index $(\mathrm{PDI})=$ $1.05)$, polystyrene $\left(M_{\mathrm{n}}=885 \mathrm{~kg} / \mathrm{mol}, \mathrm{PDI}=1.08\right)$, and poly ( $N$-methyl 2-vinyl pyridinium iodide) $\left(\mathrm{P}^{2} \mathrm{MVPI}_{228}, M_{\mathrm{n}}=\right.$ $56 \mathrm{~kg} / \mathrm{mol}, \mathrm{PDI}=1.09$ ) were purchased from Polymer Source Inc., Canada. Poly(2-vinyl pyridine) ( $\mathrm{P} \mathrm{VP}_{43}$, $\left.M_{\mathrm{n}}=4.15 \mathrm{~kg} / \mathrm{mol}, \mathrm{PDI}=1.09\right)$ was purchased from Polymer Standard Service (Mainz, Germany). The synthesis of poly(acrylic acid)- $b$-poly(acrylate methoxy poly(ethylene oxide) $\left(\mathrm{PAA}_{21}-b-\mathrm{PAPEO}_{14}, M_{\mathrm{n}}=8.86 \mathrm{~kg} / \mathrm{mol}, \mathrm{PDI}=1.4\right)$ has been described elsewhere [14]. Its structure is shown in Fig. 2. According to the molecular structure, we used 22 PAA groups in our charge calculations.

The molecular mass of each APEO graft is $450 \mathrm{~g} / \mathrm{mol}$, corresponding to a length of the PEO chains of eight to nine monomers. Styrene (99\%), iodomethane (99\%), lysozyme (Lsz) from chicken egg white (L6876-5G), $\beta$-lactoglobulin ( $\beta$-lac) from bovine milk, approximately $90 \%$ (L0130-5G), and bovine serum albumin (BSA), minimum 98\% (A7030$10 \mathrm{G})$ were purchased from Sigma. Selected properties of these proteins are listed in Table 1.

Sodium chloride $(\mathrm{NaCl})$, sodium hydroxide $(\mathrm{NaOH}$, $1 \mathrm{M})$, and hydrochloric acid ( $\mathrm{HCl}, 1 \mathrm{M})$ were purchased from Sigma. All chemicals were used as received.
Fig. 1 Schematic representation of a concept of polymer brushes formation upon adsorption of $\mathbf{A}$ regular C3Ms consisting of a linear block copolymer and a linear polyelectrolyte, $\mathbf{B}$ a model grafted block copolymer, $\mathbf{C}$ C3Ms consisting of a model grafted block copolymer and a linear polyelectrolyte
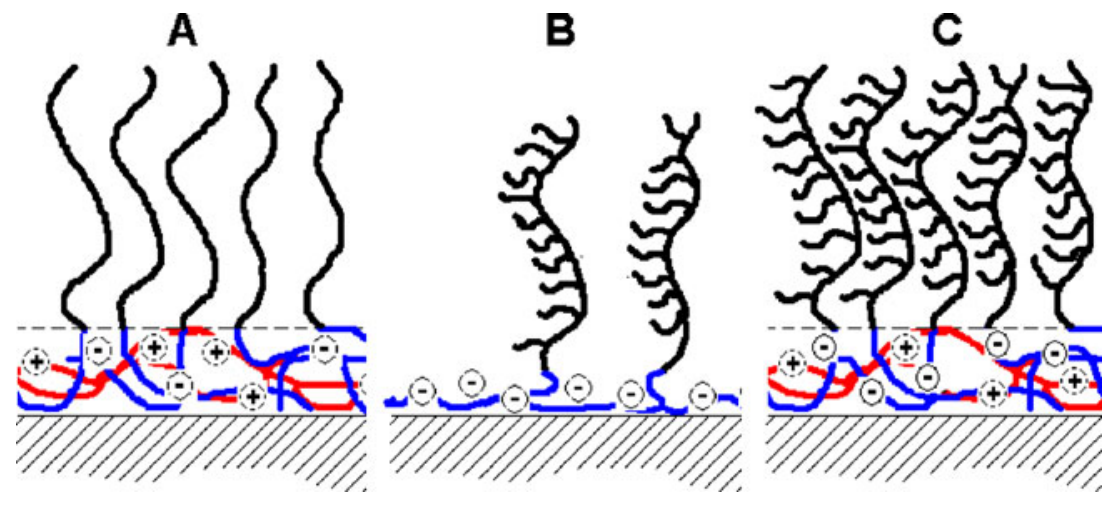


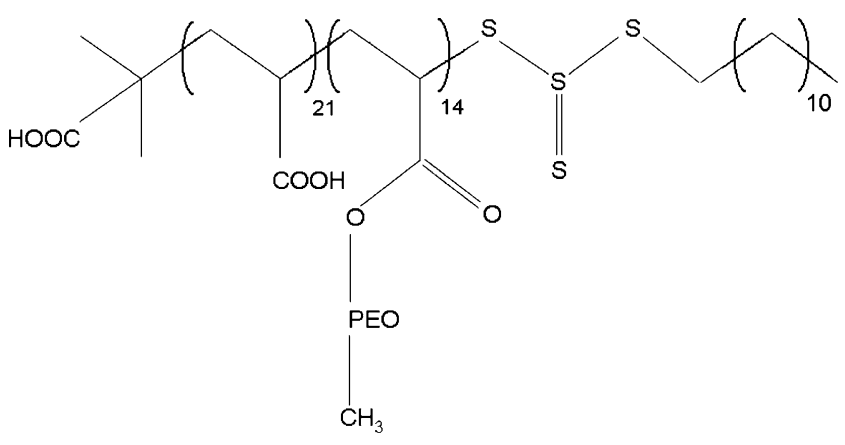

Fig. 2 Structure of $\mathrm{PAA}_{21}-b-\mathrm{PAPEO}_{14}$

Silicon wafers (boron doped, orientation 100, and resistivity $7-15 \Omega \mathrm{cm}^{-1}$ ) were purchased from WaferNet, Inc., USA.

\section{Quaternization of P2VP}

$\mathrm{P}_{2} \mathrm{VP}_{43}$ and $\mathrm{P}_{2} \mathrm{VP}_{41}-\mathrm{b}-\mathrm{PEO}_{204}$ were quaternized according to the following procedure: dissolved in $35 \mathrm{ml}$ of $N, N$ dimethylmethanamide was $1 \mathrm{~g}$ of (co)polymer. Three milliliters of iodomethane were added, and the mixture was allowed to react for $48 \mathrm{~h}$ at $60^{\circ} \mathrm{C}$, under nitrogen gas flow and stirring. A second portion of $3 \mathrm{ml}$ iodomethane was added $24 \mathrm{~h}$ after the beginning of the reaction. Subsequently, the quaternized polymer was precipitated with ether, filtered, washed several times with fresh portions of ether, and dried overnight in a vacuum oven at $48{ }^{\circ} \mathrm{C}$. The degree of quaternization of $\mathrm{P}_{2} \mathrm{MVPI}_{43}$ was determined by elemental analysis to be approximately $89 \%$ [22]. The degree of quaternization of $\mathrm{P}_{2} \mathrm{MVPI}_{41}-b-\mathrm{PEO}_{204}$ was verified by dynamic light scattering titration with $\mathrm{PAA}_{139}$ at $\mathrm{pH}$ 7. At stoichiometric charge ratio micelles are formed, and the position of the maximum intensity provides an estimation of the degree of quaternization.

\section{Characterization of grafted block C3Ms in solution}

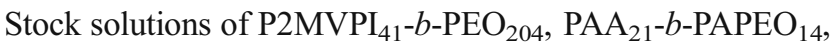
$\mathrm{P}_{2} \mathrm{MVPI}_{228}$, and $\mathrm{P}_{2} \mathrm{MVPI}_{43}$ in MilliQ water were prepared. Prior to the measurements, solutions of the required polymer and salt concentrations were prepared from stock solutions.

Table 1 Selected properties of proteins used in the experiments

\begin{tabular}{llcl}
\hline Protein & $\begin{array}{l}\text { Dimensions } \\
{\left[\mathrm{nm}^{3}\right]}\end{array}$ & $\begin{array}{l}\text { Molecular mass } \\
{[\mathrm{kg} / \mathrm{mole}]}\end{array}$ & $\begin{array}{l}\text { Isoelectric point } \\
(\mathrm{pH} \text { units })\end{array}$ \\
\hline Lsz & $3 \times 3 \times 4.5[15]$ & $14.3[15]$ & $11[15]$ \\
$\beta-\mathrm{lac}$ & $4 \times 4 \times 4[16]$ & $18.4[18]$ & $5.3[18]$ \\
BSA & $4 \times 4 \times 14[17]$ & $66.4[19]$ & $4.8-5.0[17,20,21]$ \\
\hline
\end{tabular}

The $\mathrm{pH}$ was adjusted to $7 \pm 0.1$ with 1 or $0.1 \mathrm{M} \mathrm{NaOH}$ and $\mathrm{HCl}$, when necessary.

1. Dynamic light scattering (DLS) titrations were performed in order to determine the PMC. During the titration, P2MVPI solutions were titrated into $\mathrm{PAA}_{21}-b-\mathrm{PAPEO}_{14}$ solution. The concentration of $\mathrm{PAA}_{21}-b-\mathrm{PAPEO}_{14}$ was $0.1 \mathrm{~g} / \mathrm{l}$, and the concentration of P2MVPI varied from 1 to $5 \mathrm{~g} / \mathrm{l}$. Polymer solutions were prepared in $10 \mathrm{mM}$ $\mathrm{NaCl}$. Titrations were performed using an ALV light scattering instrument equipped with an ALV_500 digital correlator and a $300 \mathrm{~mW}$ argon ion laser $(532 \mathrm{~nm})$, at $25 \pm 0.5^{\circ} \mathrm{C}$ and $90^{\circ}$ detection angle. Decalin was used as a refractive index matching medium.

2. Zeta potentials of C3Ms in solution were measured with a Nanosizer (Nano ZS, Malvern Instruments). Samples at different mixing ratios $(f-)$ of $\mathrm{PAA}_{21}-b-\mathrm{PAPEO}_{14}$ and P2MVPI were prepared in $10 \mathrm{mM} \mathrm{NaCl}$ solution. Conversion of the acrylic acid block to sodium acrylate was done by addition of a $1 \mathrm{M} \mathrm{NaOH}$ solution. The total polymer concentration was $0.5 \mathrm{~g} / \mathrm{l}$. Samples were measured $14 \mathrm{~h}$ after mixing to ensure equilibrium.

Preparation of protein solutions

Protein solutions were prepared prior to each experiment in MilliQ water with the addition of the required amount of $\mathrm{NaCl}$. The $\mathrm{pH}$ was adjusted to $7 \pm 0.1$ with 1 and $0.1 \mathrm{M}$ $\mathrm{NaOH}$ or $\mathrm{HCl}$.

Preparation of the surfaces

Silica surfaces were prepared by heating silicon wafers at $1,000{ }^{\circ} \mathrm{C}$ for about $1.5 \mathrm{~h}$. As a result, an oxide layer of 80 $100 \mathrm{~nm}$ was formed. Prior to the measurements, oxidized wafers were cut into strips of approximately $1 \times 5 \mathrm{~cm}^{2}$, immersed in a freshly prepared piranha solution (one part of $35 \% \mathrm{H}_{2} \mathrm{O}_{2}$ and two parts of $95 \% \mathrm{H}_{2} \mathrm{SO}_{4}$ ) for $2-3 \mathrm{~min}$ and rinsed with MilliQ water. Cleaned strips were stored in MilliQ water, in separate containers, to avoid contamination with dust.

Polystyrene (PS) surfaces were prepared according to the method described by Sieval et al. [23, 24] introducing slight modifications: strips of silica wafer were cleaned with a piranha solution, rinsed with MilliQ water, dried with acetone, and etched with $40 \% \mathrm{HF}$ for 2-3 min to remove an oxide layer. Etched strips were immediately transferred into a solution of styrene in toluene $(10 \%)$, and the solution was heated up to $100{ }^{\circ} \mathrm{C}$. The surface polymerization reaction continued for about $1.5 \mathrm{~h}$ under nitrogen gas flux and reflux. After the reaction the strips were rinsed with fresh toluene several times to remove ungrafted polymer and finally left to dry in air. On these chemically grafted layers, an additional layer of polystyrene was spincoated (RDE-/ 
SPINCOATER Motorcontroller, Eco Chemie B.V) from a solution in toluene $(13 \mathrm{~g} / \mathrm{l})$. Coated strips were stored in MilliQ water. Surfaces used in experiments were not older than 3-4 days, and their quality was monitored with an optical (Olympus BX60 with Olympus DP70 camera) and a SEM microscope (JEOL SEM-6480LV).

The thickness of the silica and PS layers was determined by ellipsometry (SE 400, SENTECH Instruments GmbH, Germany). The complex refractive index of the silicon layer was set to $n=3.85, \kappa=0.02$, and the refractive indexes of silica and PS layer were 1.46 and 1.56 , respectively. The thickness was measured at several positions of the strip, and an average of at least five measurements has been taken for calculation of the sensitivity factor used in reflectometry.

\section{Reflectometry}

The adsorbed amounts were determined with a fixed-angle optical reflectometer, described in detail elsewhere [25]. Changes in the measured signal $(\Delta S)$ can be related to the adsorbed amount, $\Gamma$ [milligrams per square meters], according to:

$\Gamma=Q_{\mathrm{f}} \times \frac{\Delta S}{S_{0}}$

where $Q_{\mathrm{f}}$ is the sensitivity factor [milligrams per square meters], $S_{0}$ is the initial (baseline) signal, and $\Delta S=S-S_{0}$ is a change in the signal upon adsorption on the surface. For each measurement, $Q_{\mathrm{f}}$ was calculated with "Prof. Huygens" $1.2 \mathrm{~b}$ (Dullware Software), using the refractive index increments of the adsorbates $(d n / d c)$ and the thickness of the optical spacer (the top substrate layer). The $d n / d c$ of the single components can be determined in a separate experiment (see below).

An example of the output of a typical reflectometry experiment is shown in Fig. 3. At the beginning of the experiment, a surface placed in the reflectometer cell is

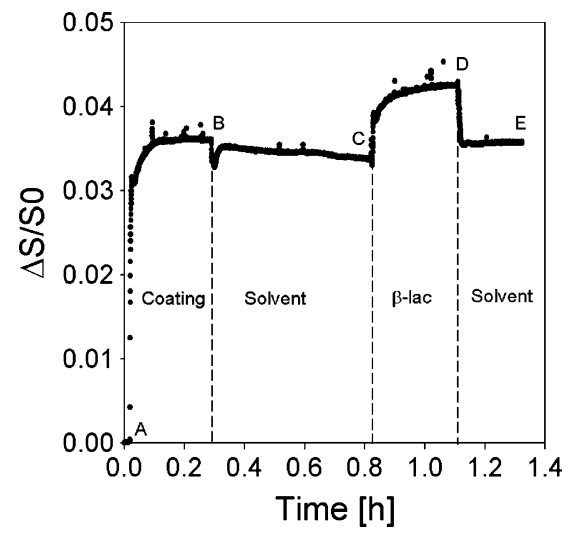

Fig. 3 Example of a typical reflectometry experiment: adsorption of $\beta$-lac on coated silica rinsed (impinging jet flow, flow rate $\approx 2 \mathrm{ml} / \mathrm{min}$, cell volume $\approx 3 \mathrm{ml}$ ) with solvent to establish the baseline signal, $S_{0}$. Subsequently, the sample solution is introduced into the cell (A) gradually replacing the solvent. Adsorption of the solute is monitored until a plateau is reached (B), followed by rinsing with solvent, and introduction of the next sample (C) and rinsing (D) until again a constant signal is obtained (E). All reported values were calculated based on amounts that remained adsorbed on the surface after rinsing with solvent, unless mentioned otherwise. Each measurement including protein adsorption was repeated at least three times, and averaged values are reported.

Determination of the refractive index increment $(d n / d c)$

Refractive index increments $(d n / d c)$ of the polymers were determined with a differential refractive index detector (Shodex RI-71, Separations). Prior to the measurements, the instrument was calibrated with $\mathrm{NaCl} . \mathrm{C} 3 \mathrm{Ms}$ and polymer solutions were prepared and measured in $10 \mathrm{mM}$ $\mathrm{NaCl}$. Conversion to sodium acrylate was done by addition of a $1 \mathrm{M} \mathrm{NaOH}$ solution. Calibration and $d n / d c$ values were determined based on at least five different concentrations of each sample.

The $d n / d c$ of the adsorbed C3Ms cannot be measured directly but has to be estimated from the corresponding values measured in solution. The experimental $d n / d c$ as measured in solution consists of two components: the $d n / d c$ of polyelectrolytes forming the C3Ms and the $d n / d c$ of the corresponding (expelled) counterions (salt). We assume that the adsorbed layer of C3Ms is homogeneous, but it is likely that this layer consists of sub-layers (complex coacervate layer, brush layer). The layer consists of a mixture of charged diblock copolymer and an oppositely charged homopolymer at stoichiometric charge ratio, assuming absence of excess salt. Therefore, the experimentally obtained value of $d n / d c$ for the C3Ms in bulk has to be corrected for the salt expelled upon C3M formation before using it in calculations of the $Q_{\mathrm{f}}$ values. The detailed calculation procedure is presented in Appendix 1.

The values of $d n / d c$ measured for $\mathrm{PAA}_{21}-b-\mathrm{PAPEO}_{14}$ and $\mathrm{C} 3 \mathrm{Ms}$ corrected for salt and the values measured for polyelectrolytes and proteins [2], used in further calculations, are listed in Table 2.

\section{Results and discussion}

Formation of grafted block C3Ms in solution

Formation of micellar particles by mixing a grafted block copolymer with an oppositely charged polyelectrolyte has been studied by DLS titrations as a function of the mixing 
Table 2 Values of refractive index increments $(d n / d c$, [cubic centimeters per gram]) used for calculations

\begin{tabular}{|c|c|c|}
\hline Compound & Solvent & $\mathrm{dn} / \mathrm{dc}$ \\
\hline \multicolumn{3}{|l|}{ Proteins: } \\
\hline Lsz [2] & buffer & 0.250 \\
\hline$\beta$-lac [2] & buffer & 0.196 \\
\hline BSA [2] & buffer & 0.204 \\
\hline \multicolumn{3}{|l|}{ Polymers: } \\
\hline $\mathrm{PAA}_{21}$-b- $\mathrm{PAPEO}_{14}$ & salt & 0.148 \\
\hline $\mathrm{P}_{2} \mathrm{MVPI}_{43}$ & salt & 0.204 \\
\hline $\mathrm{P}^{2} \mathrm{MVPI}_{228}$ & salt & 0.213 \\
\hline \multicolumn{3}{|l|}{ C3Ms: } \\
\hline C3M-PAPEO ${ }_{14} / \mathrm{P}_{2} \mathrm{MVPI}_{43}$ & salt & 0.162 \\
\hline C3M-PAPEO $14 / \mathrm{P}_{2} \mathrm{MVPI}_{228}$ & salt & 0.159 \\
\hline
\end{tabular}

"Buffer" stands for $50 \mathrm{mM}$ phosphate buffer; "salt" stands for $10 \mathrm{mM}$ $\mathrm{NaCl}$

ratio $f$-. The mixing ratio $f$-is defined as the fraction of the negatively chargeable groups assuming that $89 \%$ of the monomers in $\mathrm{P}_{2} \mathrm{VP}_{43}$, and $85 \%$ of the monomers, as determined by the supplier, in $\mathrm{P}_{2} \mathrm{VP}_{228}$ is quaternized.

$f-=\frac{[-]}{([-]+[+])}$

$[-]$ and $[+]$ are the total number of moles of negatively and positively chargeable groups, respectively. The PMC, i.e., the mixing ratio at which the maximum number of micelles (C3Ms) are formed [9] can be determined from the position of the maximum scattering intensity (if the size of the micelles does not vary or only weakly varies with $f$-). Experimental results for mixing $\mathrm{PAA}_{21}-b-\mathrm{PAPEO}_{14}$, with $\mathrm{P}_{2} \mathrm{MVPI}_{43}$ or $\mathrm{P}_{2} \mathrm{MVPI}_{228}$ are shown in Fig. 4a, b, respectively.

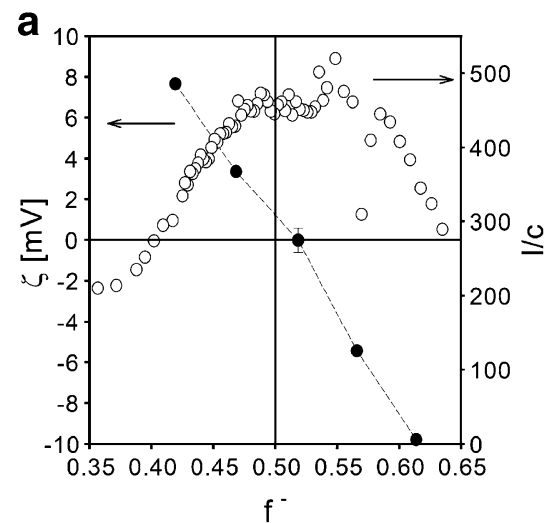

Fig. 4 Formation of C3Ms in bulk as measured with DLS titrations and zeta potential measurements. Left Y axis zeta potential, right Y axis scattering intensity [kilohertz] divided by the total concentration, c [grams per liter], of the polymer. Symbols: open circle DLS titration
C3Ms are formed by the oppositely charged polyelectrolytes mixed at stoichiometric charge ratio. The neutral corona surrounding the complex coacervate core prevents the coacervate from growing to macroscopic dimensions. Thus, at $f-=0.5$, electrically neutral particles are expected. Determination of the zeta potentials for different mixing ratios $(f-)$ reveals that, in a solution at stoichiometric charge ratio $(f-=0.5), \mathrm{C} 3 \mathrm{Ms}$ are, within experimental error, electrically neutral. The $d \zeta / d f$ - values are almost identical for both systems and do not differ for negatively and positively charged aggregates (Fig. 4). For the short homopolymer, the isoelectric point corresponds well to the PMC, i.e., the maximum in the scattering intensity. However, for the long homopolymer, the maximum number of micelles is found if the aggregates carry an excess positive charge, i.e., at $f=0.45$. In this case, the maximum scattering intensity is more pronounced than for the short homopolymer. We relate this observation to the limited flexibility of the grafted block copolymer, resulting from the presence of the side chains. Apparently, due to the steric effect, the negatively charged $\mathrm{PAA}_{21}$-blocks are easier to access, i.e., can be more effectively neutralized, by the positively charged groups on short $\mathrm{P}_{2} \mathrm{MVPI}_{43}$ than by the charged groups of the long $\mathrm{P}_{2} \mathrm{MVPI}_{228}$. All C3Ms in this study were prepared at compositions corresponding to maximum in scattering intensity (PMC), i.e., at $f=0.5$ for C3M-PAPEO ${ }_{14} / \mathrm{P}_{2} \mathrm{MVPI}_{43}$ and at $f-0.45$ for C3M$\mathrm{PAPEO}_{14} / \mathrm{P}_{2 \mathrm{MVPI}} 228$.

The hydrodynamic radii of the C3M-PAPEO $14 / \mathrm{P}_{2} \mathrm{MVPI}_{43}$ and C3M-PAPEO ${ }_{14} / \mathrm{P}_{2} \mathrm{MVPI}_{228}$, as determined with DLS titrations, are 105 and $85 \mathrm{~nm}$, respectively, and do not vary significantly in the $f$-range between 0.4 and 0.6 . The large hydrodynamic radii determined experimentally suggest that the discussed C3Ms are not regular micelles but rather aggregates consisting of small micelles. These small micelles aggregate

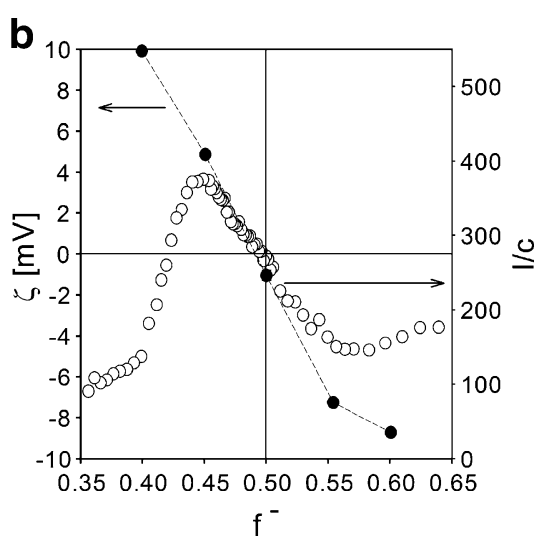

curves of $\mathrm{PAA}_{21}-b$-PAPEO 14 with $\mathrm{P}_{2 \mathrm{MVPI}_{43}}$ (a) and $\mathrm{P}_{2} \mathrm{MVPI}_{228}$ (b) in $10 \mathrm{mM} \mathrm{NaCl}, \mathrm{pH} \mathrm{7}$, closed circle zeta potentials of C3M-PAPEO 14 $\mathrm{P}_{2} \mathrm{MVPI}_{43}$ (a) and $\mathrm{C} 3 \mathrm{M}-\mathrm{PAPEO}_{14} / \mathrm{P}_{2} \mathrm{MVPI}_{228}$ (b) measured at various mixing ratios $(f-)$ in $10 \mathrm{mM} \mathrm{NaCl}, \mathrm{pH}$ 7. Lines were added to guide the eye 
due to hydrophobic interactions most probably originating from the hydrophobic end-group in the $\mathrm{PAA}_{21}-b$ - $\mathrm{PAPEO}_{14}$ molecule (see Fig. 2). A more detailed discussion on the structure of these aggregates will be presented in a forthcoming paper.

Stability of grafted block C3Ms in a solution

\section{Stability against salt}

The stability of the C3Ms in solution is strongly dependent on the strength of the interactions between the polyelectrolytes in the coacervate core. At low salt concentration, electrostatic attraction between oppositely charged polyelectrolytes is strong, but, with increasing salt concentrations, electrostatic interactions are more and more screened. At salt concentrations higher than $50 \mathrm{mM} \mathrm{NaCl}$, the scattering intensity of C3M-PAPEO ${ }_{14} / \mathrm{P}_{2} \mathrm{MVPI}_{43}$ in solution decreases, and the observed hydrodynamic radii of $\mathrm{C} 3 \mathrm{Ms}$ increase to values above $250 \mathrm{~nm}$. Above $200 \mathrm{mM} \mathrm{NaCl}$, the scattering intensity of C3M-PAPEO $14 / \mathrm{P}_{2} \mathrm{MVPI}_{43}$ stabilizes at $60 \%$ of its value at $1 \mathrm{mM} \mathrm{NaCl}$. A similar decrease in scattering intensity and increase in the hydrodynamic radii is observed for C3M-PAPEO ${ }_{14} / \mathrm{P}_{2} \mathrm{MVPI}_{228}$ at salt concentrations above $100 \mathrm{mM} \mathrm{NaCl}$. Above $400 \mathrm{mM} \mathrm{NaCl}$, the scattering intensity of C3M-PAPEO ${ }_{14} / \mathrm{P}_{2} \mathrm{MVPI}_{228}$ stabilizes at $40 \%$ of its initial value. Thus, grafted block C3Ms are sensitive to salt concentration and partly disintegrate beyond $50-100 \mathrm{mM} \mathrm{NaCl}$.

\section{Stability against proteins}

Polyelectrolytes are known to form complexes with proteins. Formation of such complexes and their solubility

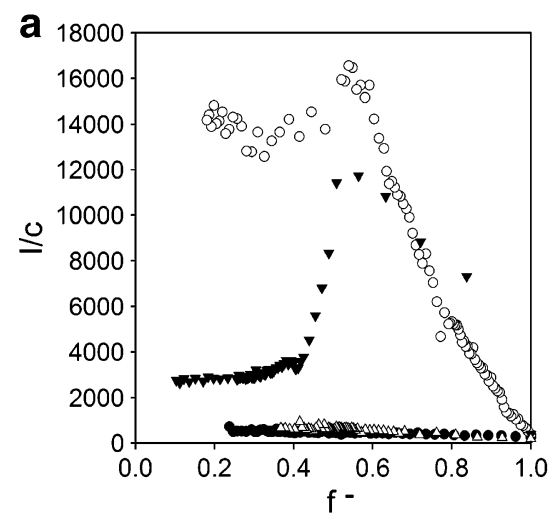

Fig. 5 DLS titrations of $\beta$-lac (a) and BSA (b) with the following polymers: open circle $\mathrm{P}_{2} \mathrm{MVPI}_{43}$, inverted closed triangle $\mathrm{P} 2 \mathrm{MVPI}_{228}$, open triangle $\mathrm{P} 2 \mathrm{MVPI}_{41}-b-\mathrm{PEO}_{204}$, closed circle $\mathrm{PAA}_{21}-b-\mathrm{PAPEO}_{14}$. The initial concentration of protein and the initial concentration of the polymer titrant were $100 \mathrm{mg} / \mathrm{l}$. Titrations were carried out in $10 \mathrm{mM} \mathrm{NaCl}, \mathrm{pH} 7 \pm 0.1$. For P2MVPI $43, \mathrm{P}_{2} \mathrm{MVPI}_{228}$, and $\mathrm{P}_{2} \mathrm{MVPI}_{41}-b-\mathrm{PEO}_{204}, f$ - on the abscissa is defined as [protein-]/ depend on several factors, such as sign and density of the charges on the protein and the polyelectrolyte, flexibility of the polyelectrolyte chain enabling closer contact between charged groups [26], concentrations of polyelectrolyte and protein in solution [27-29], ionic strength [30,31], and $\mathrm{pH}$ [32]. Complexation between a polyelectrolyte and a protein may even occur at the "wrong" side of the isoelectric point, i.e., under conditions where the polyelectrolyte and the protein have the same sign for the overall charge. This phenomenon is related to charge regulation of the proteins [33] or to non-homogeneous distribution ("patches") of positive and negative charges on the protein surface [34]. Formation of polyelectrolyte-protein complexes may have an influence on the functionality (i.e., suppression of protein adsorption) of the coatings created upon adsorption of $\mathrm{C} 3 \mathrm{Ms}$ on solid-liquid interfaces. Therefore, we studied the aggregation between BSA and $\beta$-lac, and the polyelectrolytes present in the grafted block $\mathrm{C} 3 \mathrm{Ms}$ at $\mathrm{pH}$ 7. During each experiment, the polyelectrolyte solution was titrated into a fixed volume of the protein solution. Experimental results are shown in Fig. 5a, b.

DLS titrations show that $\beta$-lac forms aggregates with the positively charged P2MVPI irrespective of their length (Fig. 5a). Here, $f$ - is defined as [protein- $] /([$ protein- $]+$ $[\mathrm{P} 2 \mathrm{MVPI}+])$ and [protein- $] /([$ protein- $]+[\mathrm{PAA}-])$ for titrations of P2MVPI groups and PAA groups, respectively. With excess $\mathrm{P}_{2} \mathrm{MVPI}_{43}$, aggregates of $\beta$-lac remain stable, whereas aggregates formed with $\mathrm{P}_{2} \mathrm{MVPI}_{228}$ disintegrate if an excess of homopolymer is added, i.e., $f-<0.5$. With the positively charged block copolymer ( $\left.\mathrm{P}^{2} \mathrm{MVPI}_{41}-b-\mathrm{PEO}_{204}\right)$, reduced scattering intensity $(\mathrm{I} / \mathrm{c})$ is very low and formation of aggregates is prevented by stabilization due to the neutral PEO block. The negatively charged copolymer seems to have no interaction with $\beta$-lac. Aggregates are also formed

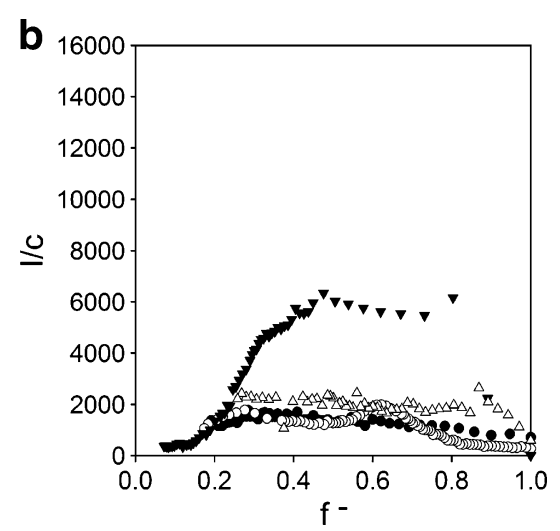

$([$ protein- $]+[\mathrm{P} 2 \mathrm{MVPI}+])$, and for $\mathrm{PAA}_{21}-b$-PAPEO ${ }_{14} f$ - is defined as [protein- $] /([$ protein-] + [PAA-]). Ordinate: intensity $I$ [kilohertz, au] divided by the total protein concentration $c$ [grams per liter]. For calculations, we assumed that under experimental conditions, BSA has 13 negative charges per molecule [35] and $\beta$-lac has 13 negative charges per dimer [36] 
between the long homopolymer, $\mathrm{P}_{2} \mathrm{MVPI}_{228}$, and BSA (Fig. 5b). With an excess of homopolymer, these aggregates remain stable between $f=0.4$ and 0.8 . However, the scattering intensity is much lower for aggregates formed between BSA and the short homopolymer, $\mathrm{P}_{2} \mathrm{MVPI}_{43}$. This may be due to the low charge density on the protein surface [26-28]. Under the experimental conditions, BSA was assumed to carry 13 negative charges per molecule [35] and $\beta$-lac, 13 negative charges per dimer [36]. Considering the difference in size of both proteins, it implies that BSA has a lower density of negative charges and may require a longer polycation to form aggregates. Contrary to $\beta$-lac, for BSA, a substantial scattering intensity around $f=0.5$ is also found in mixtures with $\mathrm{P}_{2} \mathrm{MVPI}_{41}-b-\mathrm{PEO}_{204}$ and $\mathrm{PAA}_{21}-b$ $\mathrm{PAPEO}_{14}$, indicating formation of aggregates.

Adsorption of grafted block copolymer and grafted block $\mathrm{C} 3 \mathrm{Ms}$ on silica and polystyrene

Adsorption of grafted block C3Ms on silica and polystyrene was studied with fixed-angle optical reflectometry. Experimental results are presented in Fig. 6a, b, respectively.

The adsorbed amount of grafted block C3Ms on silica and polystyrene is much higher than the adsorption of the single grafted block copolymer. The adsorption properties of the micelles with short and long homopolymer differ significantly. Initial adsorption is fast and then levels off to reach a relatively stable level within 1 or $2 \mathrm{~h}$. Upon rinsing with solvent, indicated by arrows in Fig. 6, any reversibly adsorbed fraction is removed. The adsorbed amount of $\mathrm{C} 3 \mathrm{Ms}$ with the long homopolymer is much lower than of C3Ms with the short homopolymer. The reversibly adsorbed fraction of micelles is much smaller for C3M$\mathrm{PAPEO}_{14} / \mathrm{P}_{2} \mathrm{MVPI}_{228}(5-10 \%)$ on both silica and polystyrene. The adsorbed amounts of micelles with the long homopolymer on silica and polystyrene are almost equal. It is likely that for the long homopolymer C3Ms adsorb primarily according to a mechanism proposed by van der Burgh et al. [4] and Voets et al. [10]. C3Ms are expected to unfold upon adsorption in a way that the coacervate core adsorbs directly on the surface, and the neutral corona forms a brush layer on top of the coacervate layer and do not disintegrate during the adsorption process. Base on these assumptions, the thickness of an unfolded C3M layer is roughly half the diameter of a micelle, i.e., half of the thickness of micelles which do not unfold. Unfolding of C3Ms on solid surfaces is, however, governed by a subtle balance between the stability of the micelles and the wetting properties of the surface, core, and corona [3]. The differences in the adsorbed amounts suggest that the micelles with the short homopolymer are more stable against unfolding than the micelles with the long homopolymer. It seems that, on silica, the micelles with the short homopolymer initially do not unfold and unfold only partly after rinsing with solvent. Possibly, the difference in adsorbed amounts after rinsing with solvent can be attributed to an excess of the positive charges on $\mathrm{C} 3 \mathrm{Ms}$ with long homopolymer. However, the wetting properties of polystyrene seem to fully suppress unfolding of C3M-PAPEO ${ }_{14} / \mathrm{P}_{2} \mathrm{MVPI}_{43}$ resulting in an adsorbed amount (after rinsing) being twice as high as for C3M-PAPEO $14 / \mathrm{P}_{2} \mathrm{MVPI}_{228}$.

$\mathrm{PAA}_{21}-b-\mathrm{PAPEO}_{14}$ is a bulky block copolymer. In addition to a charged PAA block, a neutral block with grafted PEO chains, it contains also a small hydrophobic end-group (-S-CS-S- $\mathrm{C}_{12} \mathrm{H}_{25}$, see Fig. 2) that originates from the initiator used to synthesize this polymer [14]. This hydrophobic "sticker" influences the structure of the C3Ms. The coacervate core and neutral corona may not be as well-defined as in typical C3Ms containing only linear polyelectrolytes resulting in relatively big micellar sizes. As a consequence, also the stability of the C3Ms in solution may be altered and the structure of the C3M layer formed upon adsorption of the micelles at the solid-liquid interface may differ from the expected one $[4,10]$. Due to an additional aggregation mechanism, the adsorbed amounts of grafted block C3Ms are higher than for regular $\mathrm{C} 3 \mathrm{Ms}$ with linear PEO blocks, described in our previous paper [2]. The structure of the adsorbed C3M layer
Fig. 6 Reversibility of the adsorption of $\mathrm{PAA}_{21}-b-\mathrm{PAPEO}_{14}$ coatings on silica (a) and PS (b). Arrows indicate the addition of the solvent. Concentrations of $\mathrm{PAA}_{21}-b-\mathrm{PAPEO}_{14}$ and $\mathrm{C} 3 \mathrm{Ms}$ in solutions were $100 \mathrm{mg} / \mathrm{l}$. Experiments were carried out at $10 \mathrm{mM} \mathrm{NaCl}, \mathrm{pH} 7 \pm 0.1$. On each graph: $1 \mathrm{C} 3 \mathrm{M}-$ $\mathrm{PAPEO}_{14} / \mathrm{P}^{2 \mathrm{MVPI}_{43}}(f-=0.50)$, 2 C3M-PAPEO 14 /P2MVPI 228 $(f-=0.45), 3 \mathrm{PAA}_{21}-b-\mathrm{PAPEO}_{14}$
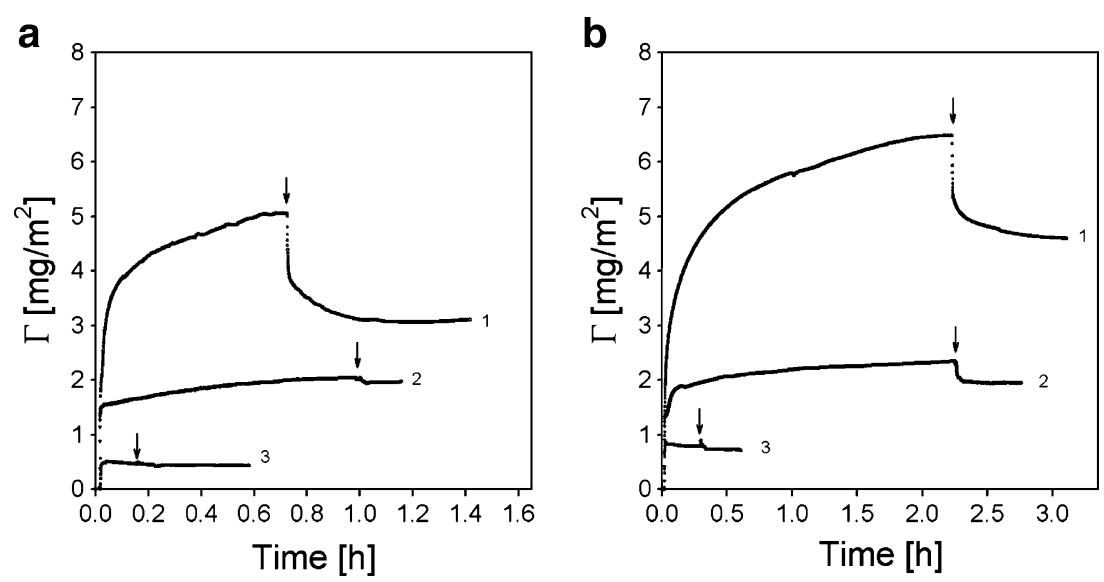
determines the formation and the density and, therewith, the functionality of the polymer brush.

As shown in Fig. 7a, after rinsing with solvent, adsorption of C3Ms on silica depends weakly on the salt concentration, if at all. On polystyrene (Fig. 7b), the adsorbed amounts of $\mathrm{C} 3 \mathrm{Ms}$ increase with increasing salt concentration except for C3M-PAPEO ${ }_{14} / \mathrm{P}_{2} \mathrm{MVPI}_{43}$ at $100 \mathrm{mM}$. Decrease in the adsorbed amount of $\mathrm{C} 3 \mathrm{M}-\mathrm{PAPEO}_{14} / \mathrm{P}_{2} \mathrm{MVPI}_{43}$ on polystyrene observed at $100 \mathrm{mM} \mathrm{NaCl}$ may be explained by the poor stability of these micelles in a solution of high ionic strength. The adsorbed amounts of C3M-PAPEO ${ }_{14} / \mathrm{P}_{2} \mathrm{MVPI}_{43}$ on polystyrene at $100 \mathrm{mM} \mathrm{NaCl}$ are the same as on silica which suggests that complete surface coverage with unfolded C3Ms was obtained. Below, we show that at $100 \mathrm{mM} \mathrm{NaCl}$ complete suppression of protein adsorption is obtained on this coating. At lower salt concentrations, the amounts of C3Ms adsorbed on polystyrene are significantly higher than on silica.

\section{Stability of the C3M layers against an excess of protein}

In order to determine the protein resistance of the surfaces coated with $\mathrm{C} 3 \mathrm{Ms}$, we exposed them to solutions of $\beta$-lac, $\mathrm{BSA}$, and Lsz. We observed that C3M-PAPEO ${ }_{14} / \mathrm{P}^{2} \mathrm{MVPI}_{43}$ layer is partly removed from the surfaces by the $\beta$-lac (Fig. 8). A similar effect was not observed for BSA or Lsz. We have shown that, in solution, $\beta$-lac forms complexes with P2MVPI at charge stoichiometric conditions. Complexes formed with the short homopolymer, P2MVPI 43 , remain stable in a solution to which an excess of homopolymer is added whereas complexes with the long homopolymer, $\mathrm{P}_{2} \mathrm{MVPI}_{228}$, disintegrate. If the PEO brush layer does not fully cover the adsorbed complex coacervate layer, one may anticipate that upon rinsing with $\beta$-lac, the adsorbed C3M-PAPEO 14 /P2MVPI 43 layer will be depleted due to interaction between the short homopolymer and $\beta$-lac.

Exposure of the surface-coated with C3M-PAPEO 14 $\mathrm{P}_{2} \mathrm{MVPI}_{43}$ to a $\beta$-lac solution leads to a reduction of the total adsorbed mass (Fig. 8a, b). This effect is much stronger on polystyrene than on silica and depends on the salt concentration. An initial increase in the adsorbed amount upon addition of $\beta$-lac corresponds to an accumulation of the protein on the adsorbed C3M layer. Immediately after this increase, the adsorbed amount decreases to a level indicating partial removal of the C3M layer from the surface.

With the following simple experiment, we confirmed that $\beta$-lac is most probably not replacing $\mathrm{P}_{2} \mathrm{MVPI}_{43}$ in the adsorbed layer but forms soluble aggregates with the homopolymer. As is discussed below, an adsorbed C3M$\mathrm{PAPEO}_{14} / \mathrm{P}_{2 \mathrm{MVPI}}{ }_{43}$ layer completely suppresses Lsz adsorption on coated surfaces. If $\beta$-lac was present in this layer, one would expect an increase in Lsz adsorption due to the electrostatic attraction between the two proteins. During the experiment $\mathrm{C} 3 \mathrm{M}-\mathrm{PAPEO}_{14} / \mathrm{P}_{2} \mathrm{MVPI}_{43}$ was exposed to $\beta$-lac and subsequently to Lsz solution. No significant adsorption of Lsz was observed.

On both silica and polystyrene at $10 \mathrm{mM} \mathrm{NaCl}$, we observe a significant reduction of the adsorbed mass but at 1 and $100 \mathrm{mM} \mathrm{NaCl}$ such effects were absent. These observations may be related to the strength of interaction between the block copolymer and the homopolymer in the C3Ms. At $1 \mathrm{mM} \mathrm{NaCl}$, electrostatic attraction between $\mathrm{P}_{2} \mathrm{MVPI}_{43}$ and $\mathrm{PAA}_{21}-b-\mathrm{PAPEO}_{14}$ is strong, and the coacervate part of $\mathrm{C} 3 \mathrm{M}$ is more glass-like [37]. Micelles in a solution are stable and form a stable layer upon adsorption at the surfaces. Thus, complexes of $\beta$-lac and $\mathrm{P}_{2} \mathrm{MVPI}_{43}$ are not formed. As the salt concentration increases, attraction between micellar components weakens.

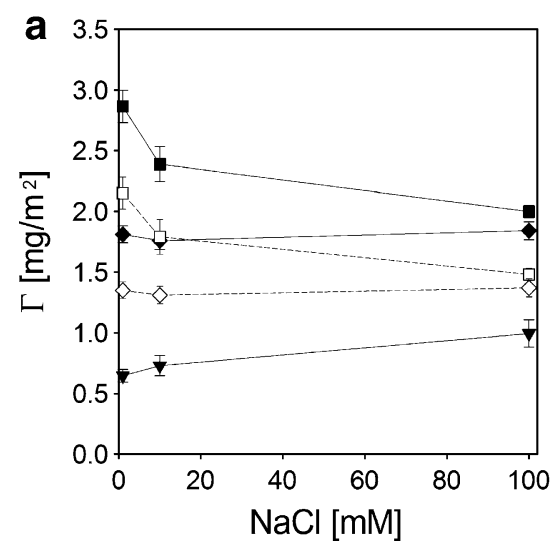

Fig. 7 Adsorption of $\mathrm{PAA}_{21}-b$-PAPEO ${ }_{14}, \mathrm{C} 3 \mathrm{M}-\mathrm{PAPEO}_{14} / \mathrm{P}_{2} \mathrm{MVPI}_{43}$ $(f-=0.5)$ and C3M-PAPEO $14 / \mathrm{P}_{2} \mathrm{MVPI}_{22}(f-=0.45)$ coatings on silica (a) and PS (b) surfaces, at various concentrations of $\mathrm{NaCl}$. Concentrations of the $\mathrm{PAA}_{21}-b$-PAPEO 14 and grafted block C3Ms in solutions were $100 \mathrm{mg} / \mathrm{l}, \mathrm{pH}$ 7. Filled symbols: filled inverted triangle $\mathrm{PAA}_{21}-b$ -

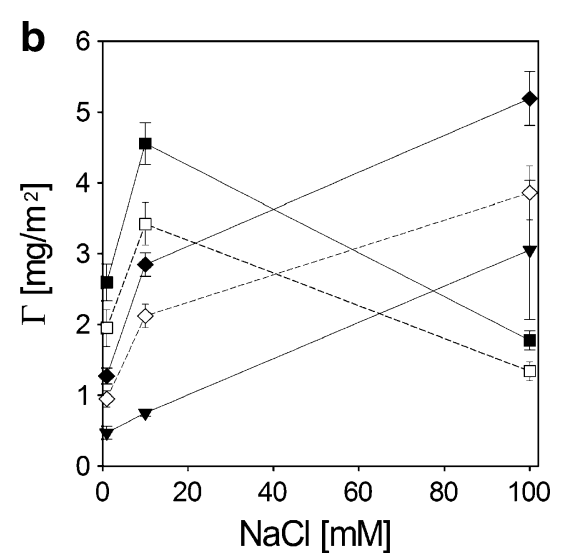

$\mathrm{PAPEO}_{14}$, filled square $\mathrm{C} 3 \mathrm{M}-\mathrm{PAPEO}_{14} / \mathrm{P}_{2} \mathrm{MVPI}_{43}$, filled diamond $\mathrm{C}_{3 \mathrm{M}-\mathrm{PAPEO}} / 4 \mathrm{P}_{2} \mathrm{MVPI}_{228}$. Open symbols correspond to the adsorbed amount of single $\mathrm{PAA}_{21}-b-\mathrm{PAPEO}_{14}$ (proportional to the amount of $\mathrm{PEO}$ in the coating) for a coating of: open square $\mathrm{C} 3 \mathrm{M}$ $\mathrm{PAPEO}_{14} / \mathrm{P}_{2} \mathrm{MVPI}_{43}$ and open diamond $\mathrm{C} 3 \mathrm{M}-\mathrm{PAPEO}_{14} / \mathrm{P}_{2} \mathrm{MVPI}_{228}$ 
Fig. 8 Reflectometry measurements showing an effect of $\beta$ lac on C3M-PAPEO $14 /$ $\mathrm{P}_{2} \mathrm{MVPI}_{43}$ layer adsorbed on silica (a) and polystyrene (b). Experiments were carried out in $10 \mathrm{mM} \mathrm{NaCl}, \mathrm{pH} 7 \pm 0.1$. Symbols on graphs: $C 3 M \mathrm{C} 3 \mathrm{M}-$ $\mathrm{PAPEO}_{14} / \mathrm{P}_{2 \mathrm{MVPI}}, S$ solvent. Concentrations of $\beta$-lac and C3M-PAPEO $14 /$ P2MVPI $_{43}$ $(f-=0.5)$ were $100 \mathrm{mg} / 1$

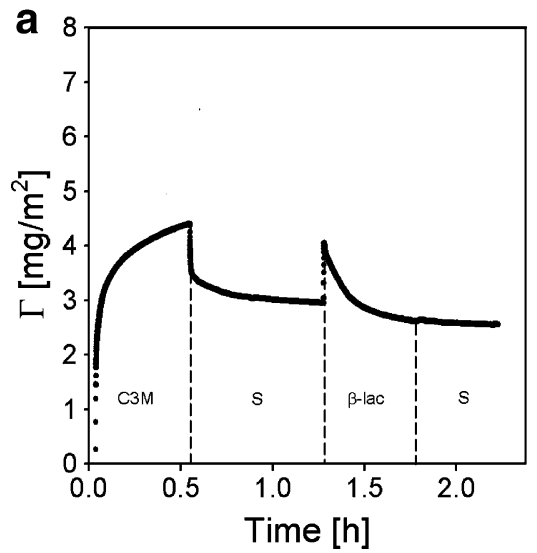

An adsorbed C3M layer may be partly penetrated by small molecules, like $\beta$-lac. Soluble complexes of $\beta$-lac and $\mathrm{P}_{2} \mathrm{MVPI}_{43}$ are formed. At salt concentrations above $50 \mathrm{mM}$ $\mathrm{NaCl}$, attraction between oppositely charged polyelectrolytes is weak, and we observe that the C3Ms partly disintegrate in solution. Under these conditions, attraction between $\beta$-lac and the oppositely charged polyelectrolyte is weak as well, and they are less likely to aggregate. A similar pattern was observed on silica.

The differences in the amount of mass removed by $\beta$-lac from silica and polystyrene may be related to the structure of the adsorbed layer and the size of the protein. Above, we have argued that, on silica, C3Ms unfold, and the P2MVPI 43 is in contact with the surface, whereas on polystyrene C3Ms do not unfold, and the short P2MVPI has no direct interaction with the solid surface, and it will be more susceptible to erosion due to complexation with $\beta$-lac by penetration through an imperfect brush layer. However, the protein may only partly penetrate the adsorbed layer due to its dimensions, which limits the erosion of the coating.

In view of the results of the experiments in solution (Fig. 5), it was expected that $\beta$-lac will not cause erosion of the adsorbed C3M-PAPEO $14 / \mathrm{P}_{2} \mathrm{MVPI}_{228}$ layer as it does not form stable soluble aggregates with $\mathrm{P}_{2} \mathrm{MVPI}_{228}$. This was confirmed by reflectometry (Fig. 9). Upon addition of $\beta$-lac, a sudden increase of the adsorbed mass is observed, followed by a stable plateau. $\beta$-lac adsorbs irreversibly on the C3M-PAPEO ${ }_{14} / \mathrm{P}_{2} \mathrm{MVPI}_{228}$ layer, i.e., it cannot be removed from the surface by rinsing with solvent.

\section{Stability of the C3Ms layer against an excess of block copolymer}

We have shown that $\beta$-lac, a relatively small, negatively charged protein may, under specific conditions, penetrate and partly remove the adsorbed $\mathrm{C} 3 \mathrm{M}-\mathrm{PAPEO}_{14} / \mathrm{P}_{2} \mathrm{MVPI}_{43}$ layer from the surface. We observed that a similar phenomenon occurs upon exposure of this coating to the negatively charged block copolymer. An adsorbed C3M-PAPEO $14 /$
$\mathrm{P}_{2} \mathrm{MVPI}_{43}$ layer is partly removed from the surface of silica and polystyrene upon rinsing with a single $\mathrm{PAA}_{21}-b$ $\mathrm{PAPEO}_{14}$ in solution. Experimental results are shown in Figs. 10 and 11. As in case of $\beta$-lac, this effect was not observed for C3M-PAPEO $14 / \mathrm{P}_{2} \mathrm{MVPI}_{228}$.

The reduction of the adsorbed amount of $\mathrm{C} 3 \mathrm{M}$ $\mathrm{PAPEO}_{14} / \mathrm{P}_{2} \mathrm{MVPI}_{43}$ upon rinsing with a $\mathrm{PAA}_{21}-b-\mathrm{PAPEO}_{14}$ solution could be explained by formation of SCPs consisting of $\mathrm{P}_{2} \mathrm{MVPI}_{43}$ and $\mathrm{PAA}_{21}-b-\mathrm{PAPEO}_{14}$. As shown in Figs. $10 \mathrm{a}$ and $11 \mathrm{a}$, it is not possible to restore the coating by simple re-adsorption of $\mathrm{P}_{2} \mathrm{MVPI}_{43}$ on the remaining layer. Subsequent exposure to $\mathrm{PAA}_{21}-b-\mathrm{PAPEO}_{14}$ did not result in increased adsorbed mass, i.e., we did not observe the formation of polyelectrolyte multilayers.

The coating can be restored by re-adsorption of C3M$\mathrm{PAPEO}_{14} / \mathrm{P}_{2} \mathrm{MVPI}_{43}$ and removed again upon exposure to $\mathrm{PAA}_{21}-b-\mathrm{PAPEO}_{14}$ (Figs. 10b and 11b). This indicates that the layer remaining on the surface is electrically neutral.

The amount of the coating remaining on the surface depends on the properties of this surface. The negatively

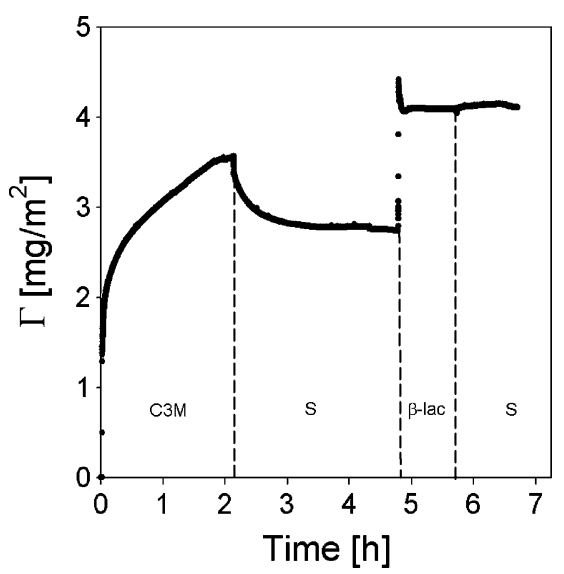

Fig. 9 Reflectometry experiment showing the effect of $\beta$-lac on a $\mathrm{C} 3 \mathrm{M}-\mathrm{PAPEO}_{14} / \mathrm{P}_{2} \mathrm{MVPI}_{228}$ layer adsorbed on polystyrene. Experiments were carried out in $10 \mathrm{mM} \mathrm{NaCl}, \mathrm{pH} 7 \pm 0.1$. Symbols on graphs: $C 3 M$ C3M-PAPEO ${ }_{14} / \mathrm{P}_{2} \mathrm{MVPI}_{228}, S$ solvent. Concentrations of $\beta$-lac and C3M-PAPEO ${ }_{14} / \mathrm{P}_{2} \mathrm{MVPI}_{228}(f-=0.45)$ were $100 \mathrm{mg} / \mathrm{l}$ 
Fig. 10 Reflectometry experiment showing an effect of $\mathrm{PAA}_{21}-b-\mathrm{PAPEO}_{14}$ on $\mathrm{C} 3 \mathrm{M}$ $\mathrm{PAPEO}_{14} / \mathrm{P}^{2} \mathrm{MVPI}_{43}(f-=0.5)$ layer adsorbed on silica. Symbols on graphs: C3M C3M$\mathrm{PAPEO}_{14} / \mathrm{P}_{2 M V P I} \mathrm{M}_{3}, S$ solvent, $B \mathrm{PAA}_{21}-b-\mathrm{PAPEO}_{14}, H$ $\mathrm{P}_{2} \mathrm{MVPI}_{43}$. Concentrations of polymers and $\mathrm{C} 3 \mathrm{M}$ PAPEO $_{14} / \mathrm{P}_{2} \mathrm{MVPI}_{43}$ were $100 \mathrm{mg} / \mathrm{l}$. Experiments were carried out in $10 \mathrm{mM} \mathrm{NaCl}$ $\mathrm{pH} 7 \pm 0.1$

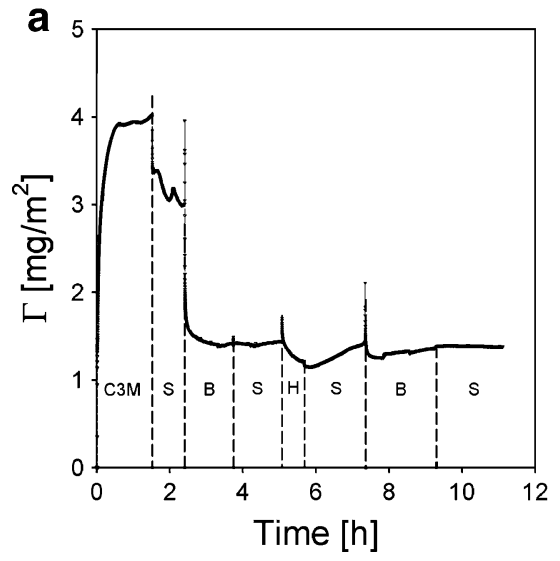

charged silica adsorbs positively charged $\mathrm{P}_{2} \mathrm{MVPI}_{43}$. To ensure electroneutrality, corresponding amount of negatively charged $\mathrm{PAA}_{21}-b-\mathrm{PAPEO}_{14}$ is bonded to this surface. Polystyrene has strong affinity to the hydrophobic tail of $\mathrm{PAA}_{21}-b-\mathrm{PAPEO}_{14}$, resulting in the accumulation of the negative charge on the surface. As on silica, to ensure electroneutrality, a corresponding amount of the positively charged $\mathrm{P}_{2} \mathrm{MVPI}_{43}$ is adsorbed on the surface. These results suggest that, under discussed conditions, the interactions between the $\mathrm{C} 3 \mathrm{Ms}$ components in the adsorbed layer are relatively weak. Upon rinsing with a $\mathrm{PAA}_{21}-b$ $\mathrm{PAPEO}_{14}$ solution, $\mathrm{PAA}_{21}-b-\mathrm{PAPEO}_{14}$ penetrates the adsorbed layer and removes its components.

The exact structure of the C3M-PAPEO ${ }_{14} / \mathrm{P}_{2} \mathrm{MVPI}_{43}$ layer remaining on the surface is unknown. Some information may be obtained upon its exposure to a protein solution. In the experiment shown in Fig. 12, we compare the adsorption of Lsz on an "etched" C3M-PAPEO 14 / $\mathrm{P}_{2} \mathrm{MVPI}_{43}$ layer with adsorption of Lsz on a $\mathrm{PAA}_{21}-b$ $\mathrm{PAPEO}_{14}$ coating. Adsorption of Lsz on the C3M layer previously exposed to $\mathrm{PAA}_{21}-b$ - $\mathrm{PAPEO}_{14}$ is much higher than on $\mathrm{PAA}_{21}-b-\mathrm{PAPEO}_{14}$ coating. Thus, the structure of the "etched" layer is disrupted, i.e., the brush layer structure

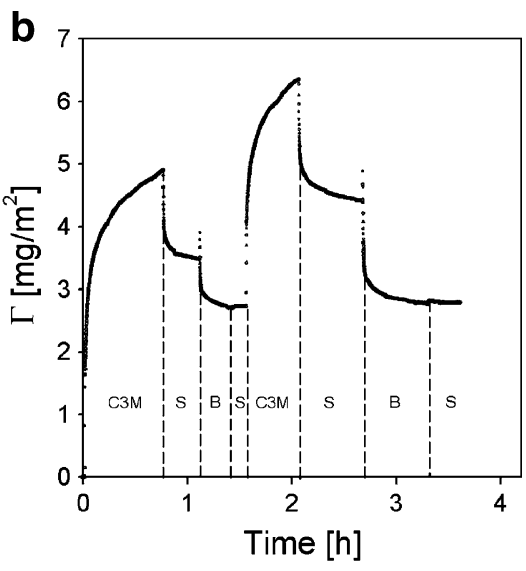

is (partly) destroyed. These results also indicate that the structure of this layer is rather loose and may be easily penetrated by small molecules, like Lsz, that can interact with its components.

Effect of grafted block C3M coatings on protein adsorption

Reduction of protein adsorption by grafted block copolymer and grafted block $\mathrm{C} 3 \mathrm{Ms}$ adsorbed on silica and polystyrene was determined with fixed-angle optical reflectometry. Reduction factors (percent) are defined with respect to the adsorption $\Gamma_{0}$ of the proteins on the native silica and polystyrene surfaces; reduction $=\left(1-\Gamma / \Gamma_{0}\right) \times 100 \%$. Experimental results are presented in Fig. 13a, b, respectively, and are in a good agreement with reported values determined under similar conditions $[3,38,39]$. In $1 \mathrm{mM} \mathrm{NaCl}$, adsorption of Lsz and BSA on silica and Lsz on polystyrene is significantly higher than at 10 and $100 \mathrm{mM} \mathrm{NaCl}$. At higher salt concentrations, protein adsorption is almost invariant with salt concentration except for Lsz. Adsorption of Lsz on polystyrene at $100 \mathrm{mM} \mathrm{NaCl}$ is higher than at lower salt concentrations. The adsorption of proteins on hydrophobic and hydrophilic surfaces at different salt
Fig. 11 Reflectometry experiment showing an effect of $\mathrm{PAA}_{21}-b-\mathrm{PAPEO}_{14}$ on C3M$\mathrm{PAPEO}_{14} / \mathrm{P}_{2} \mathrm{MVPI}_{43}$ layer adsorbed on polystyrene. Symbols on graphs: $C 3 M \mathrm{C} 3 \mathrm{M}-$ $\mathrm{PAPEO}_{14} / \mathrm{P}_{2} \mathrm{MVPI}_{43}, S$ solvent, $B \mathrm{PAA}_{21}$ - $b$-PAPEO ${ }_{14}, H$ $\mathrm{P}_{2} \mathrm{MVPI}_{43}$. Concentrations of polymers and C3M-PAPEO 14 $\mathrm{P}_{2 \mathrm{MVPI}_{43}}(f-=0.5)$ were $100 \mathrm{mg} / \mathrm{l}$. Experiments were carried out in $10 \mathrm{mM} \mathrm{NaCl}$ $\mathrm{pH} 7 \pm 0.1$
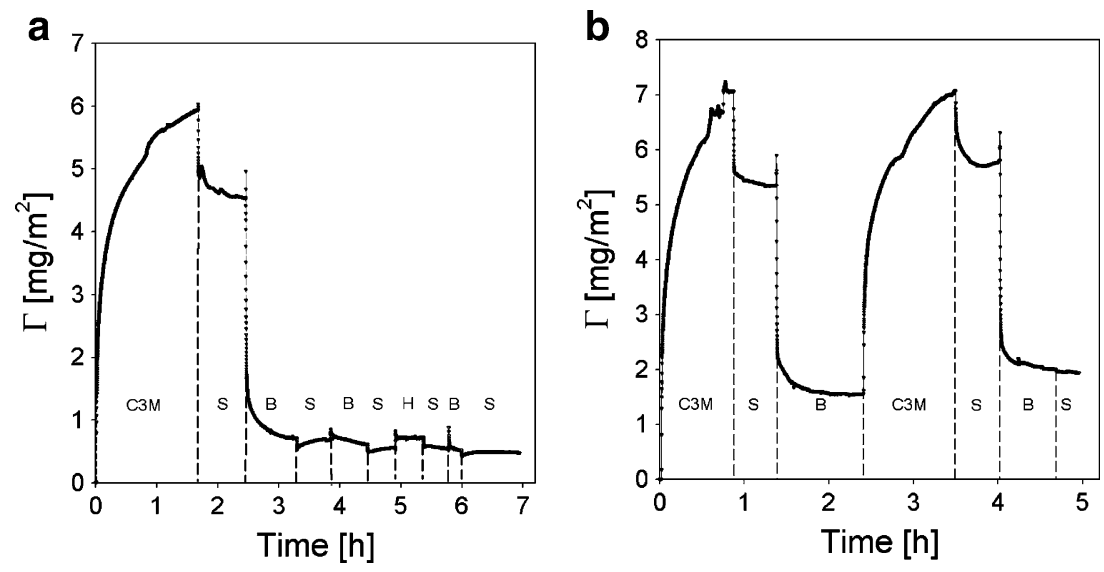
Fig. 12 Reflectometry measurements showing an adsorption of Lsz on a C3M-PAPEO 14 $\mathrm{P}_{2 \mathrm{MVPI}_{43}}(f-=0.5)$ layer exposed to $\mathrm{PAA}_{21}-b-\mathrm{PAPEO}_{14}$ (a) and on a $\mathrm{PAA}_{21}-b-\mathrm{PAPEO}_{14}$ (b) layer adsorbed on silica. Symbols on graphs: $C 3 M$ C3M-PAPEO 14 $\mathrm{P}_{2} \mathrm{MVPI}_{43}, S$ solvent, $B \mathrm{PAA}_{21}-b$ $\mathrm{PAPEO}_{14}$. Concentration of Lsz, polymers, and C3M-PAPEO ${ }_{14}$ $\mathrm{P}_{2} \mathrm{MVPI}_{43}$ were $100 \mathrm{mg} / \mathrm{l}$. Experiments were carried out at $10 \mathrm{mM} \mathrm{NaCl} \mathrm{pH} 7 \pm 0.1$
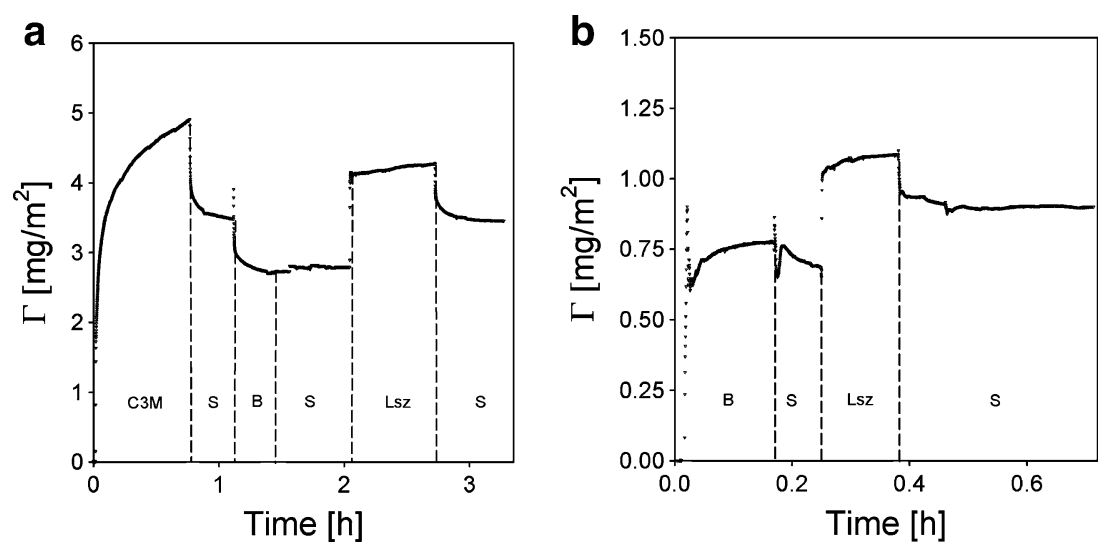

concentrations is the result of a balance between electrostatic and non-electrostatic forces. It is influenced by screening of charges, size of proteins, wetting behavior, and heterogeneity of the surface.

In Figs. 14 and 15, we present experimentally determined reduction factors for protein adsorption on surfaces coated with $\mathrm{C} 3 \mathrm{M}-\mathrm{PAPEO}_{14} / \mathrm{P} 2 \mathrm{MVPI}_{228}$ and $\mathrm{C} 3 \mathrm{M}$ $\mathrm{PAPEO}_{14} / \mathrm{P}_{2} \mathrm{MVPI}_{43}$, respectively.

From the results in Figs. 14 and 15, it follows that the properties of the coating with the long homopolymer, $\mathrm{P}_{2} \mathrm{MVPI}_{228}$, are very different from the properties of the coating with the short homopolymer, $\mathrm{P}_{2} \mathrm{MVPI}_{43}$. On a C3M-PAPEO ${ }_{14} / \mathrm{P}_{2} \mathrm{MVPI}_{228}$ layer, the adsorption of the negatively charged proteins, $\beta$-lac and $\mathrm{BSA}$, is enhanced by the coating (negative values of the reduction factor) instead of being suppressed, at salt concentrations above $10 \mathrm{mM} \mathrm{NaCl}$. Adsorption of positively charged Lsz is strongly suppressed. The grafted block C3M-PAPEO 14 $\mathrm{P}_{2} \mathrm{MVPI}_{228}$ micelles are stable in solution at salt concentrations below $100 \mathrm{mM} \mathrm{NaCl}$ and adsorb irreversibly on silica and polystyrene. The results suggest that these micelles do not have a well-defined core-corona structure and that upon their adsorption on the surfaces, they do not form a well-developed brush but rather, the positively charged polyelectrolyte is exposed to the solution. This was confirmed by zeta potential measurements (see Fig. 4b).
This effect is much more pronounced on hydrophobic polystyrene than on hydrophilic silica.

An excellent reduction of protein adsorption on silica and polystyrene coated with micelles containing the short homopolymer, C3M-PAPEO ${ }_{14} / \mathrm{P}_{2} \mathrm{MVPI}_{43}$, is obtained both for $\beta$-lac and Lsz. At 1 and $10 \mathrm{mM} \mathrm{NaCl}$, adsorption of the negatively charged BSA is only weakly repelled from the surface. At $100 \mathrm{mM} \mathrm{NaCl}$, adsorption of all proteins on both surfaces was suppressed by more than $90 \%$. These observations suggest that the coating does not completely screen the interactions between surface and proteins at low salt concentrations, and BSA can still adapt to the surface. As discussed above, these phenomena are independent of the nature of the native surface. We observed that, at salt concentrations above $50 \mathrm{mM} \mathrm{NaCl}, \mathrm{C} 3 \mathrm{M}-\mathrm{PAPEO}_{14} / \mathrm{P}_{2} \mathrm{MVPI}_{43}$ partly disintegrates in solution. Results presented in Fig. 15 confirm that, at $100 \mathrm{mM} \mathrm{NaCl}$, a fully functional brush layer is formed upon their adsorption on silica and polystyrene.

Coatings consisting of $\mathrm{PAA}_{21}-b-\mathrm{PAPEO}_{14}$ only show limited resistance towards protein adsorption. This may be related to insufficient surface coverage by the block copolymer and, as a consequence, to a low density of PEO chains. As mentioned before (see Fig. 7), adsorption of grafted block $\mathrm{C} 3 \mathrm{Ms}$ results in higher amounts of adsorbed $\mathrm{PAA}_{21}-b-\mathrm{PAPEO}_{21}$ than adsorption of single $\mathrm{PAA}_{21}-b$ $\mathrm{PAPEO}_{14}$ and thus in a higher density of the PEO chains
Fig. 13 Adsorption of proteins on native silica (a) and polystyrene (b) surfaces. Concentrations of proteins in solutions were $100 \mathrm{mg} / \mathrm{l} . \mathrm{pH} 7 \pm 0.1$. Symbols: inverted filled triangle $\beta$-lac, filled square BSA, filled diamond Lsz. Lines were added to guide the eye
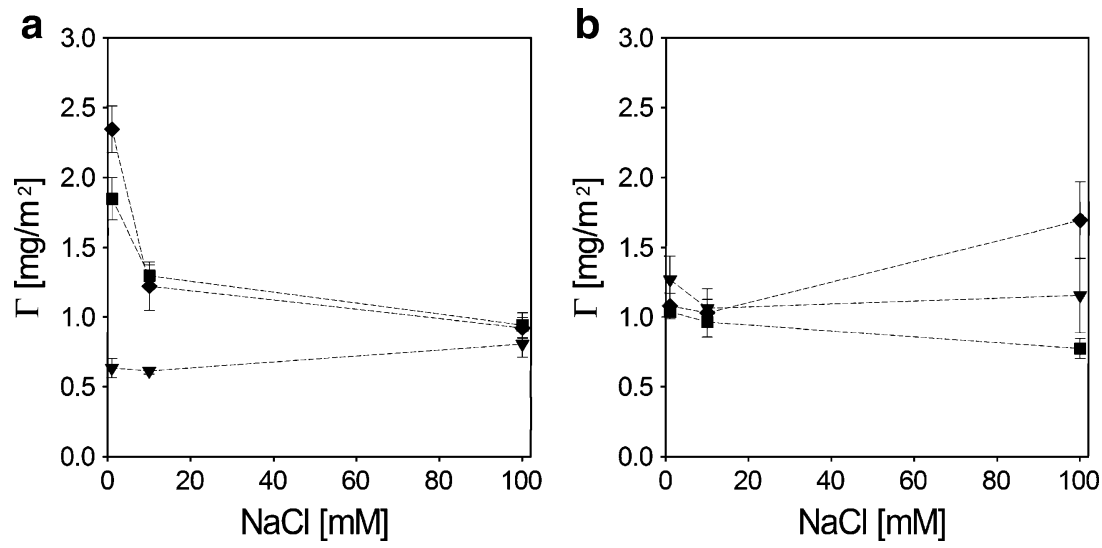


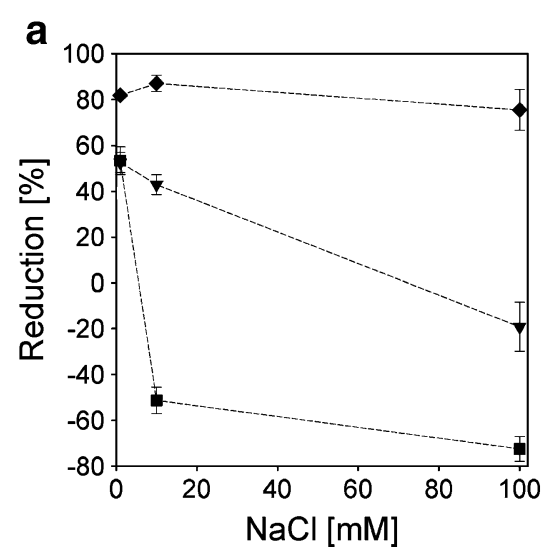

Fig. 14 Reduction factors for protein adsorption by pre-adsorbed $\mathrm{C} 3 \mathrm{M}-\mathrm{PAPEO}_{14} / \mathrm{P}^{2} \mathrm{MVPI}_{228}(f-=0.45)$ layer on silica (a) and polystyrene (b). Concentrations of proteins and grafted block C3Ms in solutions were $100 \mathrm{mg} / 1 \mathrm{pH} 7 \pm 0.1$. Symbols: inverted filled triangle

on the surface. Higher density of PEO chains is expected to result in more effective suppression of protein adsorption. However, results presented for C3M-PAPEO ${ }_{14} / \mathrm{P}_{2} \mathrm{MVPI}_{228}$ are not in agreement with this expectation. Our results show that the structure of the adsorbed C3Ms layer is influenced by the length of the polyelectrolyte blocks and does not allow for the exposure of all PEO chains to the solution.

\section{Conclusions}

Grafted block complex coacervate core micelles are formed upon mixing $\mathrm{PAA}_{21}-b-\mathrm{PAPEO}_{14}$ with P2MVPI at stoichiometric charge ratios. Their stability in solution strongly depends on the block length of the homopolymer and the salt concentration. At $\mathrm{pH} \mathrm{7,C3Ms} \mathrm{containing} \mathrm{the} \mathrm{short}$

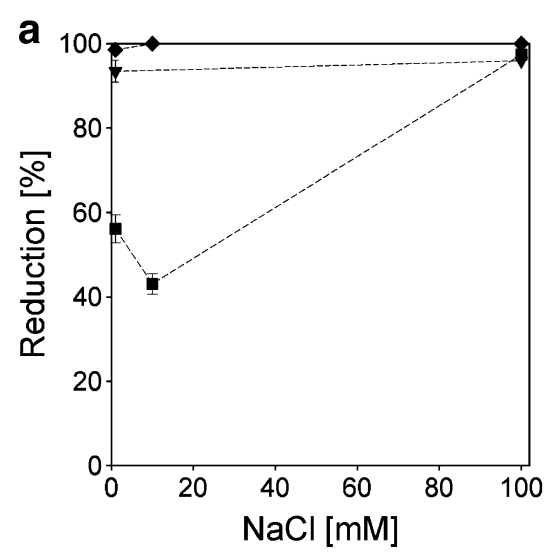

Fig. 15 Reduction factor for protein adsorption by a pre-adsorbed C3M-PAPEO ${ }_{14} / \mathrm{P}^{2} \mathrm{MVPI}_{43}(f-=0.5)$ layer on silica (a) and polystyrene (b). Concentrations of proteins and grafted block $\mathrm{C} 3 \mathrm{Ms}$ in solutions were $100 \mathrm{mg} / \mathrm{l}$. pH $7 \pm 0.1$. Symbols: inverted filled triangle $\beta$-lac, filled square BSA, filled diamond Lsz. Lines were added to guide the

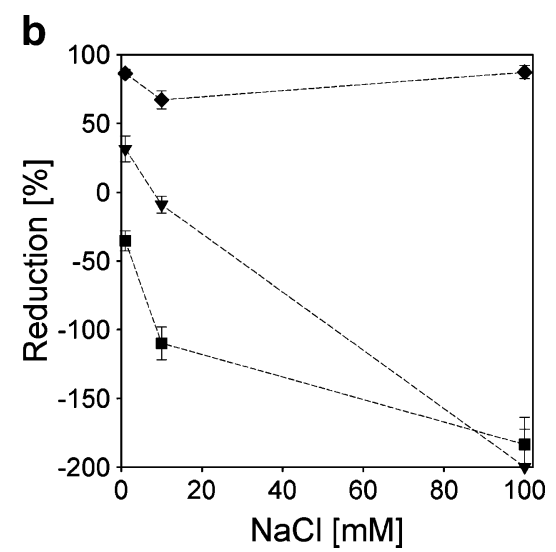

$\beta$-lac, filled square BSA, filled diamond Lsz. Lines were added to guide the eye. The negative reduction factor in $\mathbf{b}$ means higher protein adsorption on coated surfaces than on native surfaces

homopolymer, $\mathrm{P}_{2} \mathrm{MVPI}_{43}$, partly disintegrate in solution at salt concentrations above $50 \mathrm{mM} \mathrm{NaCl}$. The micelles with the long homopolymer, $\mathrm{P}_{2} \mathrm{MVPI}_{228}$, partly disintegrate at salt concentrations above $100 \mathrm{mM} \mathrm{NaCl}$. Upon adsorption at a solid-liquid interface, grafted block C3Ms form a layer that suppresses adsorption of proteins. The effectiveness of this coating depends on the charge of the aggregates, the length of the homopolymer block, and the salt concentration. The adsorption of grafted block C3Ms results in a higher density of neutral PEO chains on the surface than the adsorption of the single grafted block copolymer, $\mathrm{PAA}_{21}-b$ $\mathrm{PAPEO}_{14}$. At $100 \mathrm{mM} \mathrm{NaCl}$, the C3M-PAPEO ${ }_{14} / \mathrm{P}_{2} \mathrm{MVPI}_{43}$ layer reduces protein adsorption on silica and polystyrene by more than $90 \%$. However, the C3M-PAPEO 14 / $2 \mathrm{MVPI}_{228}$ layer enhances the adsorption of the negatively charged proteins at salt concentrations above $1 \mathrm{mM} \mathrm{NaCl}$. It suggests that adsorbed $\mathrm{C} 3 \mathrm{M}-\mathrm{PAPEO}_{14} / \mathrm{P}_{2} \mathrm{MVPI}_{228}$ do not

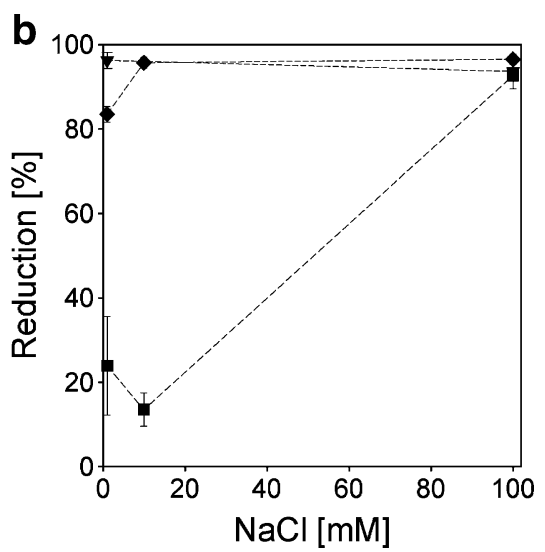

eye. Results for the reduction of $\beta$-lac adsorption on C3M-PAPEO 14 $\mathrm{P}_{2} \mathrm{MVPI}_{43}(f-=0.5)$ layer are not included in the graph. Due to the effect this protein has on the coating, it is not possible to quantitatively determine the reduction factor for its adsorption 
form a well-structured bilayer with a coacervate layer attached to the surface and a PEO brush layer exposed towards the solution, but that the positively charged blocks are also penetrating the brush layer. These findings were confirmed by zeta potential measurements which show an excess of positive charge on C3M-PAPEO ${ }_{14} / \mathrm{P}_{2} \mathrm{MVPI}_{228}$ while C3M-PAPEO ${ }_{14} / \mathrm{P}_{2} \mathrm{MVPI}_{43}$ were found to be nearly neutral. The C3M-PAPEO $14 / \mathrm{P}^{2} \mathrm{MVPI}_{43}$ layer may be partly destroyed upon exposure to $\beta$-lac and to $\mathrm{PAA}_{21}-b$ $\mathrm{PAPEO}_{14}$. At $10 \mathrm{mM} \mathrm{NaCl}$, these molecules form soluble aggregates with the polyelectrolytes extracted from the adsorbed C3Ms layer. This results in a significant decrease in the adsorbed mass on the surface.

A well-developed PEO brush layer is not only required to effectively reduce protein adsorption but is also crucial to protect the complex coacervate layer from being solubilized by supplying an excess of block copolymer or protein.

Acknowledgments This work was performed in the TTIWcooperation framework of Wetsus, Centre of Excellence for Sustainable Water Technology (www.wetsus.nl). Wetsus is funded by the Dutch Ministry of Economic Affairs, the European Union Regional Development Fund, the Province of Fryslân, the City of Leeuwarden and the EZ/Kompas program of the "Samenwerkingsverband NoordNederland". The authors thank the participants of the research theme "Biofouling" for the discussions and their financial support.

C.D. thanks the Politique Scientifique Fédérale in the frame of the Interuniversity Attraction Pôles Programme (PAI VI/27): Supramolecular Chemistry and Supramolecular Catalysis, and the National Funds for Scientific Research (F.R.S.-FNRS) for financial support.

Open Access This article is distributed under the terms of the Creative Commons Attribution Noncommercial License which permits any noncommercial use, distribution, and reproduction in any medium, provided the original author(s) and source are credited.

\section{Appendix 1: Estimation of $d n / d c$ of an adsorbed C3M layer}

The $d n / d c$ value of an adsorbed C3M layer follows from its value in solution minus a correction for the expelled salt upon neutralization of the oppositely charged chains. We assume that all salt is expelled. The experimental value of $d n / d c$ of C3Ms in solution can be derived from the $d n / d c$ values of the charged homopolymer (HP) and the oppositely charged diblock copolymer (DB). It is important to note that $d n / d c$ values are determined in milliliters per gram, but that the additivity is on a molar basis.

If the components of a C3M layer are homogeneously distributed in a volume element of that layer, the contributions of refractive indices of the different components will be additive and one can write:

$n_{\text {layer }}=\Delta n_{\mathrm{HP}}+\Delta n_{\mathrm{DB}}-\Delta n_{\text {salt }}+n_{\text {solvent }}$
Taking the derivate with respect to the molar concentration of the building block (bb) one gets:

$\frac{d n_{\text {layer }}}{d C_{\mathrm{bb}}}=\frac{d n_{\mathrm{HP}}}{d C_{\mathrm{bb}}}+\frac{d n_{\mathrm{DB}}}{d C_{\mathrm{bb}}}-\frac{d n_{\mathrm{salt}}}{d C_{\mathrm{bb}}}$

where $C$ is expressed in moles per liter.

A building block is defined as the sum of the diblock copolymer, without corresponding counter ions, and the amount of homopolymer, also without counterions, corresponding to the number of charges in the diblock copolymer. The experimental value for the $d n / d C$ of C3Ms follows from those of the homopolymer and the diblock copolymer by

$\frac{d n_{\mathrm{C} 3 \mathrm{M}}}{d C_{\mathrm{bb}}}=\frac{d n_{\mathrm{HP}}+d n_{\mathrm{DB}}}{d C_{\mathrm{bb}}}=\frac{d n_{\mathrm{HP}}}{d C_{\mathrm{bb}}}+\frac{d n_{\mathrm{DB}}}{d C_{\mathrm{bb}}}$

The conversion of $d n / d C$ (in liters per mole) to $d n / d c$ (in liters per gram) follows from:

$C_{\mathrm{bb}}=c_{\mathrm{bb}} / M_{\mathrm{bb}}=c_{\mathrm{C} 3 \mathrm{M}} /\left(M_{\mathrm{HP}}^{\prime}+M_{\mathrm{DP}}\right)$

$C_{\mathrm{bb}}=C_{\mathrm{C} 3 \mathrm{M}}=\left(c_{\mathrm{HP}}+c_{\mathrm{DP}}\right) /\left(M_{\mathrm{HP}}^{\prime}+M_{\mathrm{DB}}\right)$

$C_{\mathrm{bb}}=C_{\mathrm{HP}}^{\prime}=c_{\mathrm{HP}} / M_{\mathrm{HP}}^{\prime}$

$C_{\mathrm{bb}}=C_{\mathrm{DB}}=c_{\mathrm{DB}} / M_{\mathrm{DB}}$

$C_{\mathrm{bb}} \times X=C_{\text {salt }}=c_{\text {salt }} / M_{\text {salt }}$

The HP marked with apostrophe corresponds to the homopolymer present in the building block, i.e., homopolymer without the counterions. Combining Eq. 6a-e with Eqs. 4 and 5 results in relations for the additivity check of the $d n / d c$ of the C3M in solution (Eq. 7) and for the salt correction for the $d n / d c$ of the surface layer (Eq. 8). In Eq. 8, the symbol " $X$ " corresponds to the number of charges of the diblock copolymer.

$$
\begin{aligned}
\left(\frac{d n}{d c}\right)_{\mathrm{C} 3 \mathrm{M}, \exp }= & \left(\frac{d n}{d c}\right)_{\mathrm{HP}, \exp } \times \frac{M_{\mathrm{HP}}^{\prime}}{\left(M_{\mathrm{HP}}^{\prime}+M_{\mathrm{DP}}\right)} \\
& +\left(\frac{d n}{d c}\right)_{\mathrm{DB}, \exp } \times \frac{M_{\mathrm{DB}}}{\left(M_{\mathrm{HP}}^{\prime}+M_{\mathrm{DP}}\right)}
\end{aligned}
$$

$$
\begin{aligned}
\left(\frac{d n}{d c}\right)_{\mathrm{C} 3 \mathrm{M}, \text { layer }}= & \left(\frac{d n}{d c}\right)_{\mathrm{C} 3 \mathrm{M}, \exp } \times \frac{M_{\mathrm{HP}}^{\prime}+M_{\mathrm{DB}}}{M_{\mathrm{bb}}} \\
& -\left(\frac{d n}{d c}\right)_{\text {salt,exp }} \times \frac{X \times M_{\text {salt }}}{M_{\mathrm{bb}}}
\end{aligned}
$$


Similarly, one can calculate $d n / d c$ of homo and block copolymers on the surface:

$$
\begin{aligned}
\left(\frac{d n}{d c}\right)_{\text {polymer,layer }}= & \left(\frac{d n}{d c}\right)_{\text {polymer,exp }} \times \frac{M_{\text {polymer,exp }}}{M_{\text {polymer }}} \\
& -\left(\frac{d n}{d c}\right)_{\text {salt,exp }} \times \frac{X \times M_{\text {salt }}}{M_{\text {polymer }}}
\end{aligned}
$$

\section{References}

1. Halperin A (1999) Polymer brushes that resist adsorption of model proteins: design parameters. Langmuir 15(7):2525-2533

2. Brzozowska AM, Hofs B, de Keizer A, Fokkink R, Cohen Stuart MA, Norde W (2009) Reduction of protein adsorption on silica and polystyrene surfaces due to coating with complex coacervate core micelles. Colloids Surf A Physicochem Eng Asp 347:146155

3. Hofs B, Brzozowska A, de Keizer A, Norde W, Cohen Stuart MA (2008) Reduction of protein adsorption to a solid surface by a coating composed of polymeric micelles with a glass-like core. J Colloid Interface Sci 325(2):309-315

4. van der Burgh S, Fokkink R, de Keizer A, Cohen Stuart MA (2004) Complex coacervation core micelles as anti-fouling agents on silica and polystyrene surfaces. Colloids Surf A Physicochem Eng Asp 242(1-3):167-174

5. Cohen Stuart MA, Besseling NAM, Fokkink RG (1998) Formation of micelles with complex coacervate cores. Langmuir 14:6846-6849

6. Kabanov AV, Bronich TK, Kabanov VA, Yu K, Eisenberg A (1996) Soluble stoichiometric complexes from poly( $N$-ethyl-4vinylpyridinium) cations and poly(ethylene oxide)-block-polymethacrylate anions. Macromolecules 29(21):6797-6802

7. Kataoka K, Togawa H, Harada A, Yasugi K, Matsumoto T, Katayose S (1996) Spontaneous formation of polyion complex micelles with narrow distribution from antisense oligonucleotide and cationic block copolymer in physiological saline. Macromolecules 29(26):8556-8557

8. Borisov OV, Zhulina EB (2002) Effect of salt on self-assembly in charged block copolymer micelles. Macromolecules 35(11):44724480

9. van der Burgh S, de Keizer A, Cohen Stuart MA (2004) Complex coacervation core micelles. Colloidal stability and aggregation mechanism. Langmuir 20(4):1073-1084

10. Voets IK, de Vos WA, Hofs B, de Keizer A, Cohen Stuart MA, Steitz R, Lott D (2008) Internal structure of a thin film of mixed polymeric micelles on a solid/liquid interface. J Phys Chem B 112 (23):6937-6945

11. Pasche S, De Paul SM, Voros J, Spencer ND, Textor M (2003) Poly(L-lysine)-graft-poly(ethylene glycol) assembled monolayers on niobium oxide surfaces: a quantitative study of the influence of polymer interfacial architecture on resistance to protein adsorption by ToF-SIMS and in situ OWLS. Langmuir 19(22):9216-9225

12. VandeVondele S, Voros J, Hubbell JA (2003) RGD-Grafted polyl-lysine-graft-(polyethylene glycol) copolymers block non-specific protein adsorption while promoting cell adhesion. Biotechnol Bioeng 82(7):784-790

13. Zhang ZP, Ma HW, Hausner DB, Chilkoti A, Beebe TP (2005) Pretreatment of amphiphilic comb polymer surfaces dramatically affects protein adsorption. Biomacromolecules 6(6):3388-3396
14. Aquil A, Vasseur S, Duguet E, Passirani C, Benoît JP, Roch ARM, Jérôme R, Jérôme C (2008) PEO coated magnetic nanoparticles for biomedical application. Eur Polym J 44:3191-3199

15. Burton WG, Nugent KD, Slattery TK, Summers BR, Snyder LR (1988) Separation of proteins by reversed-phase high-performance liquid-chromatography.1. Optimizing the column. J Chromatogr 443:363-379

16. Wong DWS, Camirand WM, Pavlath AE (1996) Structures and functionalities of milk proteins. Crit Rev Food Sci Nutr 36 (8):807-844

17. Bosma JC, Wesselingh JA (1998) $\mathrm{pH}$ dependence of ion-exchange equilibrium of proteins. AIChE J 44(11):2399-2409

18. Marsh RJ, Jones RAL, Sferrazza M (2002) Adsorption and displacement of a globular protein on hydrophilic and hydrophobic surfaces. Colloids Surf B Biointerfaces 23(1):31-42

19. Tarasevich YI, Monakhova LI (2002) Interaction between globular proteins and silica surfaces. Colloid J 64(4):482-487

20. Bachmann L, Schmittfumian WW, Hammel R, Lederer K (1975) Size and shape of fibrinogen .1. Electron-microscopy of hydrated molecule. Makromol Chem-Macromol Chem Phys 176(9):26032618

21. Hirayama K, Akashi S, Furuya M, Fukuhara K (1990) Rapid confirmation and revision of the primary structure of bovine serum-albumin by esims and Frit-Fab Lc Ms. Biochem Biophys Res Commun 173(2):639-646

22. Voets IK, de Vries R, Fokkink R, Sprakel J, May RP, de Keizer A, Cohen Stuart MA (2009) Towards a structural characterization of charge-driven polymer micelles. Eur Phys J E 30(4):351-359

23. Currie EPK, Sieval AB, Avena M, Zuilhof H, Sudholter EJR, Cohen Stuart MA (1999) Weak polyacid brushes: preparation by LB deposition and optically detected titrations. Langmuir 15 (21):7116-7118

24. Sieval AB, Demirel AL, Nissink JWM, Linford MR, van der Maas JH, de Jeu WH, Zuilhof H, Sudholter EJR (1998) Highly stable Si-C linked functionalized monolayers on the silicon (100) surface. Langmuir 14(7):1759-1768

25. Dijt JC, Cohen Stuart MA, Hofman JE, Fleer GJ (1990) Kinetics of polymer adsorption in stagnation point flow. Colloids Surf 51:141-158

26. Cooper CL, Goulding A, Kayitmazer AB, Ulrich S, Stoll S, Turksen S, Yusa S, Kumar A, Dubin PL (2006) Effects of polyelectrolyte chain stiffness, charge mobility, and charge sequences on binding to proteins and micelles. Biomacromolecules 7(4):1025-1035

27. Kabanov VA, Evdakov VP, Mustafaev MI, Antipina AD (1977) Cooperative bonding of serum-albumin by quaternized poly-4vinylpyridines and structure of complexes formed. Mol Biol 11 (3):443-454

28. Kayitmazer AB, Seyrek E, Dubin PL, Staggemeier BA (2003) Influence of chain stiffness on the interaction of polyelectrolytes with oppositely charged micelles and proteins. J Phys Chem B 107(32):8158-8165

29. Morawetz H, Hughes WL (1952) The interaction of proteins with synthetic polyelectrolytes.1. Complexing of bovine serum albumin. J Phys Chem 56(1):64-69

30. Matsunami H, Kikuchi R, Ogawa K, Kokufuta E (2007) Light scattering study of complex formation between protein and polyelectrolyte at various ionic strengths. Colloids Surf B Biointerfaces 56:142-148

31. Seyrek E, Dubin PL, Tribet C, Gamble EA (2003) Ionic strength dependence of protein-polyelectrolyte interactions. Biomacromolecules 4(2):273-282

32. Hallberg RK, Dubin PL (1998) Effect of $\mathrm{pH}$ on the binding of beta-lactoglobulin to sodium polystyrenesulfonate. J Phys Chem B 102(43):8629-8633 
33. de Vos WM, Biesheuvel PM, de Keizer A, Kleijn JM, Cohen Stuart MA (2008) Adsorption of the protein bovine serum albumin in a planar poly(acrylic acid) brush layer as measured by optical reflectometry. Langmuir 24(13):6575-6584

34. Xia JL, Dubin PL, Kim Y, Muhoberac BB, Klimkowski VJ (1993) Electrophoretic and quasi-elastic light-scattering of solubleprotein polyelectrolyte complexes. J Phys Chem 97(17):45284534

35. Menon MK, Zydney AL (1998) Measurement of protein charge and ion binding using capillary electrophoresis. Anal Chem 70 (8):1581-1584
36. Fogolari F, Ragona L, Licciardi S, Romagnoli S, Michelutti R, Ugolini R, Molinari H (2000) Electrostatic properties of bovine $b$ lactoglobulin. Proteins: Struct Funct Genet 39:317-330

37. Kovacevic D, van der Burgh S, de Keizer A, Cohen Stuart MA (2002) Kinetics of formation and dissolution of weak polyelectrolyte multilayers: role of salt and free polyions. Langmuir 18 (14):5607-5612

38. Norde W, Favier JP (1992) Structure of adsorbed and desorbed proteins. Colloids Surf 64(1):87-93

39. Norde W, Gonzalez FG, Haynes CA (1995) Protein adsorption on polystyrene latex-particles. Polym Adv Technol 6(7):518-525 